\title{
The role of social integration in the adverse effect of unemployment on mental health - Testing the causal pathway and buffering hypotheses using panel data
}

\author{
Gerhard Krug ${ }^{1}$, Sebastian Prechsl ${ }^{2}$
}

This is a preprint version of an article published in

Social Science Research

https://doi.org/10.1016/j.ssresearch.2019.102379

\begin{abstract}
Social integration is considered crucially important for understanding the adverse effect of unemployment on mental health. Social integration is assumed to either bring about the health effects of unemployment (causal pathway hypothesis) or shield the unemployed from such effects (buffering hypothesis). However, there is scarce empirical evidence, especially based on panel data, regarding these two hypotheses. In our analysis, we use up to ten waves of the "Labour Market and Social Security" (PASS) German panel study and apply fixed effects panel regressions to account for unobserved confounders. We test several indicators that cover different aspects of social integration (numbers of strong and weak ties, conflict in the household, employed friends, general and job searchspecific social support). We find no empirical support for the causal pathway hypothesis and only very limited support for the buffering hypothesis.
\end{abstract}

Keywords: unemployment; mental health; social integration; social support; social networks; moderation; mediation; panel data; causal path; buffering

\section{Acknowledgements}

We thank the two anonymous reviewers, Martin Abraham, Petri Böckerman, Lea Ellwardt, Markus Promberger, Thorsten Schneider, Nico Vonneilich, and Tobias Wolbring for their valuable suggestions and comments. Earlier versions of this paper were presented, among others, at the workshop "Analytical Sociology" in Venice 2017, the session of the "Sektion Soziologische Netzwerkforschung" at the 2018 Congress of the Deutsche Gesellschaft für Soziologie in Göttingen, the "ISA RC28 Spring Meeting 2019" in Frankfurt, the 2019 SASE Meeting and the ASA 2019 Annual Meeting in New York as well as the 2019 conference of the European Consortium for Sociological Research in Lausanne. We thank all participants for their input.

\footnotetext{
${ }^{1}$ Institute for Employment Research (IAB), Germany; email: gerhard.krug@iab.de. University of ErlangenNuremberg (FAU), Germany; email: gerhard.krug@iab.de.

${ }^{2}$ Institute for Employment Research (IAB), Germany, email: sebastian.prechs12@iab.de.
} 


\section{Introduction}

Because unemployment can be a stressful life event, it disrupts the organization of people`s lives (Pearlin 1989). Detrimental effects on health, especially mental health, are a well-documented consequence of such stressful disruptions (Brand 2015, Paul and Moser 2009). However, there remains a gap in our understanding of how exactly unemployment affects mental health. This lack is unfortunate because understanding the mechanism is the precondition for developing policy measures to improve the unemployed's mental health status and thus enhance re-employability. This is not to say that such measures do not already exist (see Moore et al. 2017, Hollederer 2018). However, they are typically not based on a single causal health-enhancing mechanism but on a mixture, e.g., among social support, job search assistance and training (see e.g. Davies 1996). As a consequence, even if such measures should yield positive effects, it is still unclear what role social integration plays.

In our analysis, we want to focus on individuals' social integration and its beneficial effects as a frequently invoked explanation for why some of the unemployed are in worse mental health than others and both in worse health than the employed. Two schools of thought can be distinguished. First, some scholars consider the dissolution or weakening of people's social relationships with others to be one of the major pathways for how unemployment deteriorates mental health (the causal pathway hypothesis). They argue that social integration generally creates beneficial health effects, but unemployment changes the network such that the benefits are reduced or are no longer provided (e.g. Jahoda 1982, Warr 1987). From this perspective, policy measures that support the unemployed in maintaining their social integration during unemployment would make sense. Second, other scholars assume that social integration helps the unemployed to experience their situation as less disruptive and threatening, thereby buffering against the harmful consequences of unemployment (the buffering hypothesis) (e.g. Cohen 2004). From this perspective, in contrast, policy measures should be supported that focus especially on those of the unemployed who, even before becoming unemployed, were comparatively isolated or have only a few supportive relationships in their networks.

Given the large and still growing literature on the causal effect of social networks and mental health (Berkman et al. 2000; Smith and Christakis 2008), it would be difficult to deny the importance of social integration. In addition, there is also a sizable literature on the negative effect of unemployment (Paul and Moser 2009). However, empirical research on the causal connections among all three variables has been considerably scarcer. This situation holds for both the causal pathway and buffering hypotheses. In this paper, first, we want to contribute to the literature by testing these two theoretical mechanisms in one analysis; i.e., we go beyond the few existing tests by not focusing exclusively on one or the other aspect of social integration. Second, we use a broad range of measures, covering different aspects of social integration. Third, we use panel data from a general population survey, allowing us to account for unobserved time-constant confounders -- something not typically done in the existing literature. 
Our paper proceeds as follows. Section 2 presents the theoretical reasoning underlying the causal pathway and buffering hypotheses and derives our hypotheses. Section 3 presents the state of the research regarding the role of social integration in the mental health of the unemployed. Section 4 presents our data and operationalizations, discusses fixed effects regressions as a means to account for unobserved confounders and introduces moderation and mediation analysis as our analytical strategy. Section 5 reports the results of our empirical analysis, section 6 discusses our findings and addresses the limitations of our analysis, and section 7 concludes.

\section{Theoretical considerations and hypotheses}

There is ample empirical evidence that mental health is causally determined by unemployment (e.g., Stauder 2019, Cygan-Rehm et al. 2017, Gebel and Voßemer 2014), although some authors have also reported null effects (e.g., Böckerman and Ilmakunnas 2009, Schmitz 2011). However, the matter of which causal mechanisms are triggered after job loss and lead to negative mental health largely remains an open question. For many scholars, social integration plays a key role in this regard.

Social integration is a generic term comprising different theoretical concepts. According to Berkman et al. (2000), the extent, shape and nature of an individual's social integration and subsequent effects on health outcomes depend on factors at three levels ${ }^{3}$ : first, on the given social-structural conditions at the macro level; second, on the social relationships that form their social networks at the mezzo level; and third, on the psychosocial mechanisms embedded in the social networks at the micro level. In our singlecountry analysis, the macro context remains constant; therefore, we focus on the mezzo and micro levels. For both levels, Berkman et al. (2000) listed several sub-dimensions with various sub-sub-dimensions, and we only focus on those relevant to our study. At the mezzo level, social networks`structural features (e.g., size or homogeneity) and the characteristics of social ties (e.g., intimacy) are distinguished. At the micro level, the psychosocial mechanisms comprise, among others, social support ${ }^{4}$ (e.g., informational or emotional) and social engagement (e.g., reinforcement of meaningful social roles or interpersonal attachment).

As summarized by Thoits (2011), a variety of reasons for why social integration enhances mental health in everyday interaction have been proposed: Social integration positively affects mental health by providing belonging, companionship and everyday social support. Emotional, informational and

\footnotetext{
${ }^{3}$ Berkman et al. (2000) also addressed a fourth aspect, namely the pathways (health behavioral, psychological and physiological) that transmit the health effects of social integration.

${ }^{4}$ The provision of social support differs based on the intimacy of social ties. According to Granovetter (1973), others who are connected to the ego via strong ties are also likely to be connected to each other via weak ties. In contrast, others to whom the ego is connected via weak ties are often unconnected. Whereas strong ties are more motivated to share their resources, weak ties provide more non-redundant support, i.e., resources that cannot be provided by other network members. Despite their different properties, Thoits (2011) argued that both types of ties are important contributors to an individual's health, although for different reasons.
} 
instrumental support obtained from the social network sustains the receiver's self-esteem, sense of mattering and perceived control over minor or impending obstacles, thus leading to positive mental health outcomes. Positive psychological states, which are decisive for mental health outcomes, are also influenced by role identities since social roles provide purpose and meaning in life and, in the case of successful role performance, engender self-esteem and a sense of control over life. Furthermore, social integration affects health behaviors through social influence, social control and role expectations.

Regarding the role of social integration in the causal relationship between unemployment and mental health, two distinct theoretical strands can be found in the literature. One strand assumes that social integration causally mediates the effect of unemployment in the sense that changes in social integration help to induce the causal effect. The other strand assumes causal buffering, in which the adverse effect of unemployment depends on the individual's ability to activate social resources through his or her social network.

\section{The causal pathway hypothesis}

Regarding the causal pathway hypothesis, the literature has commonly held that a weakening or dissolution of social integration constitutes at least one of the pathways through which unemployment causes mental health to deteriorate. For example, a common theoretical framework in unemployment research is Jahoda's (1981) concept of latent deprivation. According to this concept, if individuals lose their jobs, social contacts are one of five latent functions of work lost, in addition to the manifest function of income provision (the others are time structure, collective purpose, social identity/status, and activity). The loss of these latent functions causes distress among the unemployed. In Warr's (1987) conceptual framework for analyzing how work and unemployment impact health, interpersonal contacts are one of the key “vitamins", i.e., environmental determinants of mental health.

There are many reasons why unemployment can severely and negatively influence social integration (see Jones 1988 for an overview). First, almost by definition, unemployment separates individuals from routine interactions with their former colleagues (Jahoda 1982). Second, the unemployed might tend to actively withdraw from certain social contacts. Through reduced income, unemployment can create financial restrictions that prevent individuals from participating in costly social activities (Warr 1987), leading to financial stress, which dissolves social support (Kong et al. 1993), impedes the capacity to reciprocate in social exchange (Sattler and Diewald 2010) or more generally leads to feelings of shame (Rantakeisu et al. 1999) and therefore to network withdrawal. Furthermore, scarce financial resources can cause conflicts within households, change the composition of household members (Sattler and Diewald 2010) or even lead to the dissolution of households due to the breakup of partnerships (Gallie et al. 2003). However, not only are informal relationships disrupted by unemployment, but the unemployed are also less likely to actively participate in formal voluntary associations (Wilcock and Franke 1963). Third, the dissolution of social ties might be initiated by the unemployed individual's 
social contacts themselves, who feel embarrassed by the job loser's low social status or blame him/her for the situation. Additionally, due to reduced resources, the unemployed are less able to return favors and thus are less attractive partners for social exchange. Furthermore, contacts might withdraw from the unemployed because of unemployment stigma (Paugam and Russel 2000; Klärner and Knabe 2016).

In summary, the causal pathway hypothesis states that social connections have a beneficial effect on mental health regardless of employment status, but since unemployment leads to a weakening or dissolution of social relationships, the unemployed are deprived of the health-promoting effects of social integration. Therefore, our first hypothesis is as follows:

Hypothesis 1: Social integration is a mechanism in the causal pathway linking unemployment to mental health.

\section{The buffering hypothesis}

The above view of social integration as a causal mechanism between unemployment and health contrasts with the equally comprehensive but mostly unconnected literature on social support. From the causalpathway perspective, social integration provides beneficial health effects regardless of the occurrence of stress, but unemployment changes social relationships such that the benefits are reduced or are no longer provided. From the causal-buffer perspective, the key assumption is that individuals need only to activate social support from their networks in cases of stressful life events or conditions, such as unemployment (Cassel 1976, Cobb 1976). Thus, the buffering literature has often implicitly assumed that social integration remains unchanged and that the benefits of this network are reaped only in cases of need (Thoits 1982).

The literature on buffering has often focused on social support in the form of resources provided or not to the individual by significant others (Umberson et al. 2010), and it has distinguished between perceived and actually received social support, with the typical result that perceived support is more important for buffering against the adverse effects of stress (Uchino 2009). While received social support refers to concrete interactions with others and the actual provision of social support, perceived social support refers to the belief and trust of an individual that social support is available to him/her (Shor et al. 2013). Wethington and Kessler (1986) argued that the perception of available support renders stressful situations seem less threatening and more manageable, thus alleviating their adverse effects on mental health. However, the buffering hypothesis is not limited to social support alone. Even if not all network members are likely to provide social support, it is generally acknowledged that social support is connected to social embeddedness (Wellman 1981; Berkman et al. 2000; Faber and Wassermann 2002; Uchino 2004). Therefore, our second hypothesis is as follows:

Hypothesis 2: The negative causal effect of unemployment on mental health is buffered against by social integration. 


\section{State of empirical research}

Despite a comprehensive literature on the health benefits of social relationships in general (cf., Berkman et al. 2000) and social support in particular (cf., Thoits 2011, Shor et al. 2013), empirical evidence regarding the causal pathway hypothesis or the buffering hypothesis has been somewhat scarce. Given the empirical evidence regarding the effects of unemployment on social network dissolution (Diewald 2007, Atkinson et al. 1986) or isolation (Gallie et al. 2001), the existence of a causal pathway seems obvious. However, the complete causal chain connecting unemployment, social integration and health has been rarely investigated. In Kessler et al. (1987), marital strain and the frequency of informal contact with neighbors, friends or relatives were not found to mediate the effect of unemployment on mental or physical health. The authors analyzed a sample from one area of the US. Janlert and Hammarström (2009) used data from 1,044 school leavers and found that the amount of social support at age 30, measured by the availability of social interaction and the availability of attachment, mediates the negative effect on physical health of the total amount of time in unemployment between the ages of 16 and 30 but not the negative effect of the same variable on mental health. Janlert and Hammarström (2009) used longitudinal information, but to the best of our knowledge, the only study that used panel data and explicitly controlled for unobserved confounders was from Krug and Eberl (2018). Based on a general population survey and panel data regressions, the authors found that neither the number of strong ties (close friends and relatives outside the household) nor the availability of weak ties through memberships in voluntary leisure organizations mediates the causal effect of unemployment on selfrated health and mental health.

For the buffering hypothesis, the situation is similar. A wealth of empirical evidence exists documenting the alleviating effect of social integration on the effect of stress on mental health, but actual research regarding the potentially stressful event of unemployment has been much rarer. Several authors have applied cross-sectional data analysis. For example, Kessler et al. (1988) showed that, among the unmarried, social support, measured as integration into affiliative networks and access to intimate and confiding relationships, buffers against the effect of unemployment on both physical and mental illness. Axelsson and Ejlertsson (2002) focused on young adults and their mental health and found buffering effects of social support from fathers, mothers and relatives among men, as well as buffering effects of social support from friends and the availability of close contacts outside the home among women. In contrast, Åslund et al. (2014) showed with Swedish data that tangible social support and memberships in organizations do not buffer against the effect of unemployment on psychosomatic symptoms and psychological well-being.

Among those based on longitudinal data, the study by Atkinson et al. (1986) analyzed the buffering mechanism at two time points. The authors found a buffering of family cohesion but not for marital support or the wife's role performance for mental health among 82 male workers. In their analysis of 235 migrants from East to West Germany in three waves, Schwarzer et al. (1994) found fewer physical 
health restrictions for those who were socially supported. The authors used a combined measure of received and perceived social support. Using a sample of 100 male workers who lost their jobs due to firm closure, Gore (1978) examined various mental and physical health changes at five stages (before and after termination). The author provided descriptive evidence for better physical health of those who were able to activate social support during unemployment. Social support was measured by an index aggregating perceived support from close contacts, the frequency of activity outside the home and the perceived opportunity to engage in activities that are satisfying and that allow him/her to talk about his/her problems. The only study controlling for unobserved confounders by way of panel data fixed effects regressions was Milner et al. (2016). The authors found the negative effects of unemployment on mental health to be buffered by their summative index of perceived social support from friends and family members.

\section{Data and methods}

\section{Data}

In our analysis, we use the "Labour Market and Social Security" (PASS) German panel study (Bethmann et al. 2013, Trappmann et al. 2013). PASS is a household survey that uses a dual frame for sampling. The first subsample is a probability sample of the German residential population and includes the shortterm unemployed. The second subsample is drawn from registries of welfare benefit recipients, including the long-term unemployed. At the time of writing, ten waves were available for research, containing approximately 40,000 individuals from 25,000 households. The questionnaire ${ }^{5}$ focuses on labor market-related issues and transfer payments, as well as the material and social conditions of households and social inclusion.

Our main dependent variable is mental health ("How strongly have you been affected by mental problems, such as fear, dejection or irritability, in the past 4 weeks?”), measured on a five-point scale from "extremely" (1) to "not at all" (5). For sensitivity checks, we also conducted our analysis with a measure of self-rated health ${ }^{6}$. The key independent variables are measures of unemployment and social integration. For employment status, we follow the classification provided by PASS. First, individuals are classified as employed if they are gainfully employed beyond marginal employment. Second, individuals are classified as unemployed if they are registered as unemployed with the local employment office or if they are not registered but self-classify as unemployed ${ }^{7}$. Third, individuals are classified in

5 All of the questionnaires and PASS documentation can be downloaded from https://fdz.iab.de/en/FDZ_Individual_Data/PASS/PASS-SUF0617.aspx. Where we report questions or items from the survey, we referred to the official translation provided by the PASS.

${ }^{6}$ Based on the following question: "How would you describe your state of health in the past 4 weeks in general?". The variable was measured on a five-point scale, from "bad" (1) to "very good" (5).

${ }^{7}$ In Germany, the unemployment insurance and welfare benefit system has a high coverage rate. In our data, only 336 observations are from individuals who consider themselves unemployed, without being registered at 
a residual category, "out of labor force", if they report their current status as retiree, homemaker, apprentice, or student (at school or university) or if they are currently on parental leave, in military service, in civilian service, or in further training. To measure social integration, we use several different indicators that focus on the different aspects of social integration at both the mezzo level (social networks) and the micro level (psychological mechanisms) (Berkman et al. 2000).

Our first measure of social integration is the natural log number of close friends or family members outside the household ${ }^{8}$. This measure captures the size of the part of the network that consists of strong ties. According to Granovetter (1973), tie strength is a function of the following characteristics: the amount of time, emotional intensity, intimacy, and reciprocal service. Thus, strong ties focus on the more intimate relationships. Conversely, the number of active memberships in voluntary organizations measures the size of one part of the network consisting mainly of weak ties. In the terminology of Berkman et al. (2000), both measures focus on social networks at the mezzo level, combining size as an aspect of network structure with intimacy as a characteristic of network ties. Whereas Granovetter (1973) argued that intimate and non-intimate ties provide different resources, Thoits (2011) pointed out that both types of ties or resources play important roles in the individual's mental health.

The third measure, conflicts in the household, focuses on psychological mechanisms at the micro level and measures social engagement in the form of interpersonal attachment (cf., Berkman et al. 2000) within the individual's household. The measure is based on the survey question "How often do misunderstandings, tensions or conflicts occur in your household?". The variable is measured on a five point scale that we reversed to have higher values reflect lower prevalence of conflicts ("very often", "often", "sometimes", "rarely", "very rarely or never"). We recoded the scale to range from zero to four, instead of one to five, to avoid misinterpretation of the main effects in the interaction models (cf., Mayerl and Urban 2019). The measure per definition covers individuals in multi-person households, but no individuals who live in single-member households. In focusing on the interpersonal attachments of unemployed individuals with other household members, it refers to the closest ties within the ego network.

The fourth measure is derived from a name generator ${ }^{9}$ regarding the three closest confidants outside the household, and it is the total number of employed individuals among them. This variable focuses on the

their local employment offices. Omitting observations from unregistered unemployed people does not change the results of our analysis.

${ }^{8}$ To avoid negative values, we added 1 before logarithmizing the number of strong ties. Thus, a value of 0 in the logarithmized variable reflects 0 strong ties, which is especially helpful for the interpretation of the main effects in regressions with interactions, which we used to test the buffering hypothesis. We used the logarithm because we assume that the effect of an additional strong tie decreases with the overall number of strong ties in the network. However, we also conducted our analysis without logarithmizing the variable (see Tables A18 and A19), and the results did not differ substantially.

${ }^{9}$ The name generator is an instrument for obtaining network data, originally developed by Burt (1984) and applied in many general population surveys since then. In our survey, the interviewees were asked a stimulus question (name generator) to think about the person outside the household who is most important to them. Subsequently, the interviewees were asked about several characteristics of this person (gender, education, employment status) 
mezzo level of network structure in that it measures the network's tendency toward homophily in tie formation with regard to employment status. The fifth and sixth measures again focus on the psychological mechanism, specifically social support. In contrast to the usual distinction of appraisal, instrumental, informational, and emotional support, we distinguish between support related to job searches and more general social support. Both measures are based on the concept of the resource generator by van der Gaag and Snijders (2005) and adapted to the context of job search by Wolf (2009). The measures capture the perceived availability of the respective social support resources. For perceived general social support, we use a sum score of six binary indicators of different types of support (e.g., "Do you know someone whose advice you can trust?"). For job search social support, we use a sum score of four binary indicators (e.g., "Do you know someone who would point out a job vacancy to you?"). In addition to the theoretically well-established buffering effect of social support, theoretical reasoning highlights the direct influence of social support on mental health (Thoits 1982). Table A1 provides a more detailed overview of the social integration variables that we use. Table A2 provides information about the partial correlations of the social integration variables, which are weak with the two social support measures as the only exception.

By testing not one but several such indicators, we aim to obtain a broader picture regarding the role of social integration in the health of the unemployed. However, even if we go beyond what has been analyzed in the context of unemployment, we acknowledge that we are only covering some of the aspects discussed in the literature on social integration and (mental) health. Most notably, as is the case in most general population studies, network characteristics, such as density, closure or balance, which might play a role in mental health, are not available but might be important for health (cf., Klärner et al. 2019; and Ellwardt et al. 2019).

Among the indicators of social integration, only strong ties, weak ties and conflicts within the household are available for all ten waves of the panel. Job search social support was measured in waves 3, 5 and 9 . The remaining two indicators were available for waves 3 and 5. Our analytical sample is restricted to individuals with at least two observations, and we further restrict our sample to individuals in the working age range of 16 to 64 years old.

Several control variables accounting for compositional differences between employed and unemployed individuals are also included in the regressions. We must control only for time-varying factors since we conduct our regression analysis with fixed effects (see the next subsection). We include years of schooling, work experience, previous unemployment experience (dummy), number of children, household size, age groups and dummies for the survey waves. We do not include household income because, with respect to the causal pathway hypothesis, it is unclear whether the variable is on the same

and their relationship with this person (frequency of conflicts, intimacy). The procedure was also conducted for the second and third most important people. 
pathway with or an alternative causal pathway than social integration or both ${ }^{10}$. For descriptive statistics on the dependent and independent variables, including between and within standard deviations, see Table A3 in the appendix.

\section{Methods and analytic strategy}

To test the causal pathway and buffering hypotheses, we conducted two different types of tests ${ }^{11}$. Whereas the causal pathway hypothesis was tested using a mediator analysis, we implemented a moderator analysis to test whether social integration acts as a buffer. As Wu and Zumbo (2008) pointed out, the terms "mediator" and "moderator" both imply causal relationships instead of mere correlations, which is why it is important to adopt a causal research design for empirical analysis. We do so by taking full advantage of the longitudinal information in the data and conducting fixed effects panel regressions (Halaby 2004, Brüderl and Ludwig 2015). By our focusing on intra-individual change, fixed effects regression accounts for not only observed but also unobserved confounders, as long as they are constant over the observation period. A statistically significant coefficient in a fixed effects regression indicates that a within-person change between waves in the focal independent variable is associated with a withinperson change in the dependent variable. This within estimate presents a stronger argument for causality than mere static comparisons between persons with different levels of the focal dependent and independent variables (between variation) by differencing out all unobserved confounders, provided that they are constant over the observation period. The data transformation that underlies the fixed effects estimation and eliminates both unobserved and observed time-constant variables is called demeaning or within transformation.

\section{Mediator analysis}

In our test for the potential mediation effects of social integration, we follow the procedure proposed by Baron and Kenny (1986) and implement it in our fixed effects regression.

The starting point of the fixed effects estimator is the error components model:

$$
m h_{i t}=\beta_{1} u_{i t}+\boldsymbol{x}_{\boldsymbol{i t}}^{\prime} \boldsymbol{\theta}_{\mathbf{1}}+\alpha_{i}+\varepsilon_{i t}
$$

where the dependent variable $m h_{i t}$ is mental health, $u_{i t}$ is the focal independent variable unemployment, and $\boldsymbol{x}_{\boldsymbol{i}}^{\prime}$ is a vector of control variables for person $i$ at time point $t$. Furthermore, $\beta_{1}$ and the vector $\boldsymbol{\theta}_{\mathbf{1}}$ are the coefficients to be estimated, $\varepsilon_{i t}$ is the idiosyncratic and $\alpha_{i}$ the time-constant error term. The latter

\footnotetext{
${ }^{10}$ Income loss might lead to financial shame and adversely impact the health-promoting quality of social integration, but it can also impact health via pathways not related to social integration, for example, the ability to buy high-quality food. As a robustness check, we also conducted the main analyses of this paper controlling for household income, and the results were very similar (see Tables A20 and A21).

${ }^{11}$ We conducted the statistical analysis of this paper with the Stata software package, version 15.1.
} 
is eliminated by subtracting all of the variables from their person-specific means over $t$ (indicated by the bar), resulting in the following:

$$
m h_{i t}-\overline{m h}_{i}=\beta_{1}\left(u_{i t}-\bar{u}_{i}\right)+\left(\boldsymbol{x}_{\boldsymbol{i t}}-\overline{\boldsymbol{x}}_{\boldsymbol{i}}\right)^{\prime} \boldsymbol{\theta}_{\mathbf{1}}+\varepsilon_{i t}-\bar{\varepsilon}_{i} .
$$

or shorter (with $\sim$ representing the de-meaned variables):

$$
\widetilde{m h}_{i t}=\beta_{1} \tilde{u}_{i t}+\widetilde{\boldsymbol{x}}_{i t}^{\prime} \boldsymbol{\theta}_{\mathbf{1}}+\tilde{\varepsilon}_{i t} .
$$

For a mediation effect to make sense, $\beta_{1}$ should be significantly different from zero -- in our case with a negative sign. The mediator analysis is then based on two equations. First, Equation (3) is augmented by social integration $s$ as an additional independent variable, resulting in the following:

$$
\widetilde{m h}_{i t}=\beta_{2} \tilde{u}_{i t}+\gamma_{1} \tilde{s}_{i t}+\widetilde{\boldsymbol{x}}_{\boldsymbol{i t}}^{\prime} \boldsymbol{\theta}_{\mathbf{2}}+\tilde{\varepsilon}_{i t} .
$$

Second, social integration is regressed on unemployment and the control variables:

$$
\tilde{s}_{i t}=\delta_{1} \tilde{u}_{i t}+\widetilde{\boldsymbol{x}}_{i t}^{\prime} \boldsymbol{\theta}_{3}+\tilde{\varepsilon}_{i t},
$$

A mediation effect, and thus support for hypothesis 1 , is present if the indirect effect is significantly different from zero, where the indirect effect is measured as the product of $\gamma_{1}$ and $\delta_{1}$ (equivalent to the difference between $\beta_{1}$ and $\beta_{2}$ ). Statistical significance is determined by a test proposed by Sobel (1982). Additionally, we conducted the Aroian test, which is a stricter version of the Sobel test (Baron and Kenny 1986). Although the p-values tend to be slightly higher for the Aroian test, both versions lead to the same conclusions after applying standard significance levels.

\section{Moderator analysis}

The buffering hypothesis is tested by moderation analysis. A moderating factor is usually seen as something not influenced by the causal factor under investigation but rather that strengthens, weakens or suppresses the causal effect, depending on its manifestation (Wu and Zumbo 2008). The case of social integration is one of the rare cases in which theories predict both a mediator and a moderator effect.

The moderator test simply augments Equation (4) with an interaction between social integration and unemployment, leading to the following:

$$
\widetilde{m h}_{i t}=\beta_{3} \tilde{u}_{i t}+\gamma_{2} \tilde{s}_{i t}+\delta_{2}\left(\widetilde{u_{i t} \cdot s_{l t}}\right)+\widetilde{\boldsymbol{x}}_{i t}^{\prime} \boldsymbol{\theta}_{2}+\tilde{\varepsilon}_{i t},
$$

where a statistically significant (and in our case positive) coefficient $\delta_{2}$ would support hypothesis 2 .

There are two additional predictions, which are controversial in the discussion in the buffering literature. First, a "pure" moderation effect would imply that the social integration that buffers against the unemployment effect is not itself influenced by unemployment; that is, $\delta_{1}$ should be near zero and statistically insignificant. Second, support for the "strong" version of the buffering hypothesis would 
imply that, for those who are employed, the social integration that buffers against the unemployment effect should be irrelevant. In terms of Equation (6), assuming that $\tilde{u}_{i t}$ is a dummy variable that takes the value of 1 for the unemployed and 0 for employed individuals, it is equivalent to the coefficient $\gamma_{2}$ of social integration being close to zero and statistically insignificant.

\section{Results}

This section describes the results for both the causal pathway and buffering hypotheses.

Mediator test of the causal pathway hypothesis (HI)

In this subsection, we present the results for our mediator test of the causal pathway hypothesis (Table $1)^{12}$. First, from a regression based on Equation (3), we observe a significantly negative coefficient of unemployment on mental health. As shown in Column 1 of Table 1 , the estimate for $\beta_{1}$ is 0.223 for the ten-wave sample, and it varies only slightly if the regression is conducted on fewer waves. The indirect effect is based on the product of $\gamma_{1}$ and $\delta_{1}$ from Equations (4) and (5). It is interpreted as the absolute value (Column 4) of the respective unemployment effect due to the intermediate effect on social integration. As we can see, for all six indicators of social integration, the indirect effect is negligibly small and statistically insignificant. A closer look at the components of the indirect effect shows that the reasons why the respective aspects of social integration do not mediate the unemployment effect differ: The number of strong ties and the frequency of conflicts in the household have significant impacts on mental health (Column 2 of Table 1), but at the same time, they are insignificantly affected by unemployment (Column 3 of Table 1) ${ }^{13}$. Regarding weak ties and job search support, we do not find that they are significantly influenced by unemployment or that they significantly affect mental health outcomes. For employed friends and general social support, we find that, even if they are adversely impacted by unemployment, these aspects of social integration do not seem to be relevant for the individual's mental health. To summarize our results for hypothesis 1 , we found no support for the hypothesis that any of our social integration indicators lie on the causal pathway between unemployment and mental health.

Moderator test of the buffering hypothesis (H2)

The previous subsection identified two indicators of social integration that were impacted by unemployment (Table 1). Some authors have argued that, for such indicators, a moderation effect is not

\footnotetext{
12 To test whether fixed-effects regressions are necessary, instead of the otherwise more efficient random effects regressions, we conducted a Hausman test. The test led to (strong) rejection of the null hypothesis, indicating that fixed-effects regressions are to be preferred.

${ }^{13}$ An explanation for the missing effect of unemployment on the frequency of conflicts in the household could be that the measure is implicitly conditioned on the household remaining intact because single households are excluded. However, as Table A22 shows, unemployment does not increase the probability that individuals transition to single-person households.
} 
possible. However, we argue, in opposition to this "pure" buffering hypothesis, i.e., that social integration can be impacted by stressful events, but the remaining social integration can also function as a buffer against adverse health effects. Therefore, we chose to test all six indicators for moderator effects.

Table 2 reports the results of these tests, where the coefficient $\delta_{2}$ of the interaction effects indicates the amount of causal moderation. Starting with active memberships, we find no significant interaction effect and therefore no empirical support for the moderator hypothesis. In contrast, for friends and family members, a significant interaction effect is observed, lending support to hypothesis 2 . However, a significant unconditional effect also indicates that, even for employed individuals, strong ties positively impact mental health. This finding contradicts the strong version of the buffering hypothesis. Nevertheless, we view the result as being at least weak evidence for a buffering effect.

For the frequency of conflicts within the household, we observe no significant interaction effect but only a significant main effect, as is also the case for the number of employed friends. For general social support and job search social support (Models 5 and 6), we observe insignificant main effects, and the interaction coefficients are far from statistically significant as well. Therefore, the results for general and job search social support do not support hypothesis 2.

\section{Robustness and sensitivity checks}

We conducted several robustness and sensitivity checks. First, we conducted our empirical analysis with the more global health indicators of self-rated health (see Tables A7 and A8). The results were often identical but also deviated in some respects. These deviations might be due to differences in the aspects of health that both outcome variables measure. Whereas self-rated health includes both psychological and physiological aspects of health, our mental health indicator focuses on psychological health only. However, because we have no indicators of physical health that are available in all of the panel waves, no empirical test of this assumption is possible. In addition, the deviations are only minor. Second, we conducted the analysis using unemployment duration instead of the binary measure of unemployment (see Tables A9 and A10). In general, the results were qualitatively similar. Where they deviated, they provide even less support for the buffering hypothesis because the respective interaction effect of strong ties is insignificant. Third, the results of the mediator and moderator test do not change if we conduct the analysis with binary indicators for weak ties and both types of social support (see Tables A11 and A12). Fourth, because our research design is based on multiple tests of similar variables using the same data set, we applied a Bonferroni correction, adjusting the p-values for multiple tests. We find that, after considering multiple tests, even the single remaining buffering effect due to strong ties becomes insignificant. 
Table 1: Test of the causal pathway hypothesis based on fixed effects regressions

\begin{tabular}{l|c|c|c|c|c|c}
\hline Indicator for social integration & $\beta_{1}$ & $\gamma_{1}$ & $\delta_{1}$ & $\begin{array}{c}\text { Indirect } \\
\text { effect } \\
\gamma_{1} \cdot \delta_{1}\end{array}$ & $\begin{array}{c}\text { Observations } \\
\text { (persons) }\end{array}$ & Waves \\
\hline Weak ties & $-0.223 * * *$ & 0.005 & -0.008 & -0.000 & 89,184 & 1 to 10 \\
Strong ties & $(0.016)$ & $(0.008)$ & $(0.008)$ & $(0.000)$ & $(19,180)$ & \\
& $-0.223 * * *$ & $0.049 * * *$ & -0.018 & -0.001 & 89,184 & 1 to 10 \\
Tensions and conflicts & $(0.016)$ & $(0.007)$ & $(0.009)$ & $(0.000)$ & $(19,180)$ & \\
& $-0.210 * * *$ & $0.147 * * *$ & 0.013 & 0.002 & 67,912 & 1 to 10 \\
Employed confidants & $(0.019)$ & $(0.006)$ & $(0.015)$ & $(0.002)$ & $(15,084)$ & \\
& $-0.202 * * *$ & 0.029 & $-0.139 * * *$ & -0.004 & 9,894 & 3 and 5 \\
General social support & $(0.056)$ & $(0.017)$ & $(0.047)$ & $(0.003)$ & $(4,947)$ & \\
& $-0.202 * * *$ & 0.025 & $-0.146 * *$ & -0.004 & 9,894 & 3 and 5 \\
Job search social support & $(0.056)$ & $(0.017)$ & $(0.050)$ & $(0.003)$ & $(4,947)$ & 3,5 \\
& $-0.195 * * *$ & -0.001 & -0.001 & 0.000 & 14,188 & 3,5 \\
& $(0.041)$ & $(0.013)$ & $(0.034)$ & $(0.000)$ & $(5,656)$ & and 9 \\
\hline
\end{tabular}

$* * * p<0.001, * * p<0.01, * p<0.05 ;$, non-significant after a Bonferroni correction $(p=[$ significance level]/[number of models]=0.05/6=0.0083); robust standard errors in parentheses.

Data source: Panel "Labour Market and Social Security"; estimator: linear fixed effects; own calculations.

$\beta_{1}$ : Coefficient of unemployment on mental health from Equation (3); $\gamma_{1}$ : Coefficient of the respective social integration variable on mental health from Equation (4); $\delta_{1}$ : Coefficient of unemployment on the respective variable of social integration from Equation (5); Indirect effect: $\gamma_{1} \cdot \delta_{1}$; part of the unemployment-health effect mediated by the respective social integration variable; standard errors of the indirect effects based on a Sobel test; the respective values from the Aroian test slightly differ but lead to identical conclusions regarding the significance level; controls: general-education and vocational school (years), work experience (months), previous unemployment experience (yes/no), number of own children, household size, age groups, survey wave dummies; ${ }^{a)}$ single-member households excluded.

Full regression tables can be found in the appendix, Tables A4 and A5.

Table 2: Test of the buffering hypothesis based on fixed effects regressions

\begin{tabular}{|c|c|c|c|c|c|c|}
\hline Dep. var.: mental health (1-5) & & Waves $1-10$ & & Waves & and 5 & \begin{tabular}{|l} 
Waves 3, \\
5 and 9 \\
\end{tabular} \\
\hline \multirow[t]{2}{*}{ Indicator for social integration } & Weak ties & Strong ties & $\begin{array}{l}\text { Tensions } \\
\text { and } \\
\text { conflicts }^{\mathrm{d})}\end{array}$ & $\begin{array}{l}\text { Employed } \\
\text { confidants }\end{array}$ & $\begin{array}{c}\text { General } \\
\text { social } \\
\text { support }\end{array}$ & $\begin{array}{c}\text { Job } \\
\text { search } \\
\text { social } \\
\text { support } \\
\end{array}$ \\
\hline & Model 1 & Model 2 & Model 3 & Model 4 & Model 5 & Model 6 \\
\hline \multicolumn{7}{|l|}{$\begin{array}{l}\text { Employment status (ref.: } \\
\text { employed) }^{a} \text { b) }\end{array}$} \\
\hline Unemployed $\left(\beta_{3}\right)$ & $\begin{array}{l}-0.222 * * * \\
(0.018)\end{array}$ & $\begin{array}{c}-0.274 * * * \\
(0.030)\end{array}$ & $\begin{array}{c}-0.268 * * * \\
(0.038)\end{array}$ & $\begin{array}{l}-0.112 \\
(0.082)\end{array}$ & $\begin{array}{l}-0.384 * \dagger \\
(0.171)\end{array}$ & $\begin{array}{c}-0.235^{*} \dagger \\
(0.096)\end{array}$ \\
\hline $\begin{array}{l}\text { Indicator for social integration } \\
\left(\gamma_{2}\right)\end{array}$ & $\begin{array}{c}0.004 \\
(0.009)\end{array}$ & $\begin{array}{c}0.032 * * * \\
(0.009)\end{array}$ & $\begin{array}{c}0.137 * * * \\
(0.008)\end{array}$ & $\begin{array}{c}0.060 * *_{\dagger} \\
(0.023)\end{array}$ & $\begin{array}{l}-0.000 \\
(0.024)\end{array}$ & $\begin{array}{l}-0.014 \\
(0.018)\end{array}$ \\
\hline $\begin{array}{l}\text { Indicator for social integration * } \\
\text { unemployed }\left(\delta_{2}\right)\end{array}$ & $\begin{array}{l}-0.003 \\
(0.017)\end{array}$ & $\begin{array}{l}0.028 *_{\dagger} \\
(0.014)\end{array}$ & $\begin{array}{c}0.023 \\
(0.013)\end{array}$ & $\begin{array}{l}-0.051 \\
(0.036)\end{array}$ & $\begin{array}{c}0.035 \\
(0.031)\end{array}$ & $\begin{array}{c}0.011 \\
(0.026)\end{array}$ \\
\hline Controls included $?^{\mathrm{c})}$ & yes & yes & yes & yes & yes & yes \\
\hline Within $\mathrm{R}^{2}$ & 0.005 & 0.006 & 0.018 & 0.006 & 0.006 & 0.005 \\
\hline $\begin{array}{l}\text { Observations } \\
\text { (persons) }\end{array}$ & $\begin{array}{c}89,184 \\
(19,180) \\
\end{array}$ & $\begin{array}{c}89,184 \\
(19,180) \\
\end{array}$ & $\begin{array}{c}67,912 \\
(15,084) \\
\end{array}$ & $\begin{array}{c}9,894 \\
(4,947)\end{array}$ & $\begin{array}{c}9,894 \\
(4,947)\end{array}$ & $\begin{array}{l}14,188 \\
(5,656)\end{array}$ \\
\hline \multicolumn{7}{|c|}{ 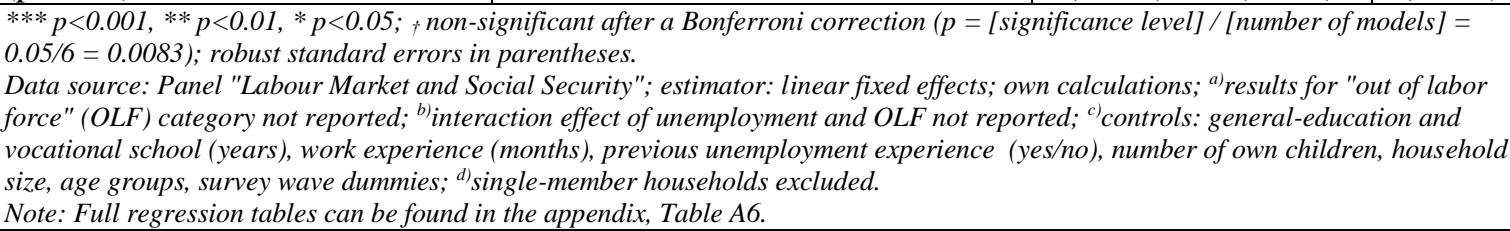 } \\
\hline
\end{tabular}


Finally, fixed effects regressions cannot control for reverse causality. Although fixed effects regressions are well suited to establishing a causal relationship between dependent and independent variables, the direction of this causal relationship is often undetermined (cf., Gunasekara et al. 2014). Therefore, reverse causality could be an alternative explanation for our results for two reasons. On the one hand, if the coefficient of unemployment on mental health reflects the selection of unhealthy workers into unemployment, there might be no causal pathway between unemployment and mental health (only in the other direction). Therefore social integration cannot lie on the causal pathway, explaining why we find no support for hypothesis 1 . On the other hand, the missing buffering effect might be explained by a causal effect of social integration on unemployment, for which a decline in social integration is the reason why workers become and stay unemployed.

To address this possibility, at least for measures available for ten waves, we investigated the mental health and social integration trajectories during employment three or more years, two year and one years before becoming unemployed, compared to being unemployed (see Tables A13 and A14 in the appendix). For social integration, we find no statistically significant downward trajectory. For mental health, we also do not observe a significant declining trajectory, but the point estimates do monotonically decline, and mental health three years and more before unemployment is ca. 0.31 points higher, two years ca. 0.24 points higher and one year before unemployment only ca. 0.16 higher than during unemployment (see Table A13). Such a pattern is indeed in line with reverse causality but could also arise due to so-called anticipation effects; i.e., the stress that goes along with anticipating becoming unemployed reduces health even before the actual job loss occurs. To fully ensure that it is not reverse causality that creates this pattern, we conducted a dynamic panel data regression and found that the coefficient of unemployment on mental health was still strong and statistically significant, even after eliminating reverse causality (see Table A15) ${ }^{14}$. In conclusion, we find that reverse causality does not explain the lack of empirical evidence regarding the buffering and causal pathway effects of social integration.

\section{Discussion and limitations}

We applied a broad range of measures of social integration to investigate the hypotheses that either they are on the causal pathway from unemployment to mental health, or they buffer against the adverse effects of unemployment. In contrast to theoretical expectations, we found that none of our measures provide empirical evidence for the causal pathway hypothesis and that only one measure, the number of strong ties, provides some limited empirical evidence for the buffering hypothesis. Regarding the causal

\footnotetext{
${ }^{14}$ We refrained from using dynamic panel data regressions throughout the paper because, especially for the mediation and moderation tests the necessary quality criteria (for further details on the methods, see Roodman (2009) were not always fulfilled. However, for the regression focused on the effect of unemployment on mental health, we found the criteria fulfilled (see Table A15).
} 
pathway hypothesis, all of the estimated indirect effects of unemployment via social integration on mental health were close to zero and insignificant. The main reason for this null result is that we did not observe the complete causal chain for any of the measures. Whereas the reduction of the number of employed friends and general social support following unemployment was statistically significant, these aspects of individuals' social integration had no effect on mental health. In contrast, both the number of strong ties and the amount of conflict in the household had statistically significant impacts on mental health, but there was no corresponding effect of unemployment on these two measures. In all, our results are in line with the previous, albeit limited, empirical evidence regarding the potential of unemployment to exert detrimental mental health effects via its adverse effects on social integration, including the only fixed effects regression (that we are aware of) that addresses the causal path hypothesis (Krug, Eberl 2018).

Regarding the buffering hypothesis, most of the measures of social integration did not significantly interact with unemployment. Only for the number of strong ties did we find significant interaction effects, but there were also several factors that cast doubt on this result. First, we also observed a significant unconditional effect, suggesting that the results are at least not in line with the strict version of the buffering thesis. Second, the results were no longer significant after a Bonferroni correction was applied. Thus, we conclude that our results for the most part contradict existing empirical evidence regarding the ability of social integration to alleviate the adverse effects of unemployment on mental health. This is also true for the only analysis of the buffering hypothesis relying panel fixed effects (Milner et al. 2016) that we are aware of. Whether the divergence in results, especially with regard to the latter analysis, is due to a different institutional context (Australia versus Germany) or different measures of social integration ${ }^{15}$ is a question our analysis cannot answer.

We acknowledge that, of course, not all our measures of social integration are ideal. On the one hand, they often do not exclusively measure only one single aspect of social integration. However, this ambiguity should nonetheless increase, rather than decrease, the likelihood of capturing the general effect of social integration on health. On the other hand, the measures are limited in that, for example, certain structural aspects of the social network could not be observed (e.g., density) or could be observed but only to a limited degree (loss of contact with former colleagues). However, although the measures do not cover all of the dimensions of social integration -- Berkman et al. (2000) listed 2 sub-dimensions for the mezzo and 5 for the micro levels, with between two and seven sub-sub dimensions each -- our measures do cover many important ones. It is also worth noting that several of our measures exhibited significant indirect and/or buffering effects in pooled OLS regression models, where unobserved

\footnotetext{
${ }^{15}$ Whereas Milner et al. (2016) measure mental health using the five-item Mental Health Inventory (MHI), a subscale from the SF-36 general health survey, with regard to social integration they focus exclusively on social support and construct a measure by taking for each individual respondent the average of 10 social support items measured on a 7-point. Then based on the observed distribution of the resulting variable coded it in three levels, representing low (1 to 4.69), medium (4.7 to 5.59), and high (5.6 to7) social support.
} 
confounders are not controlled for (see Tables A16 and A17 in the appendix). These associations disappeared once fixed effects regressions were applied, supporting our assumption that the null effects are not due to the low quality of our measures, but due to our research design controlling for unobserved confounders. Concerning our measure for mental health, to cover as many waves as possible, we have to rely on a single 5-point scale measure, whereas other studies use measures that are more complex (e.g. Milner at al. 2016). However, with a correlation of 0.69 our measure is highly related to the SF-12 mental health component scale, that has been shown to be an adequately valid and reliable measure of depressive disorders in the general population (e.g. Cheak-Zamora et al. 2009)

Fixed-effects regressions are based exclusively on the within-person variations in the data, which is both a strength and a limitation. Examining Table A3, we find that within variation in our data is sufficient for most measures of social integration. However, this point does not hold for the two social support measures, for which intra-individual changes in the amount of social support are relatively rare. This fact might pose a serious limitation, especially regarding the buffering hypothesis, because the fixedeffects estimator might have difficulty identifying interaction effects due to the low within variation. In Table A17, tests of the buffering hypothesis based on pooled ordinary least squares regression are documented. Here, we can see that the social support measures were the rare case in our data, with interactions being statistically insignificant even before applying fixed effects, undermining the argument that the fixed effects reduce the variation necessary to identify a causal effect. However, one could still argue that even the between variation of the measures is still relatively low. Future waves of the PASS surveys should not only measure the general availability of a resource but also its amount.

\section{Conclusions}

Taken together, our results speak against the importance of social integration for the unemploymentmental health relationship in two respects. First, social integration does not seem as helpful as many researchers assume it to be in alleviating the adverse effects of unemployment on health. Second, although unemployment leads to adverse health effects, it seems to leave the social integration of unemployed individuals largely intact. This outcome does not mean that social integration is not important for mental health. Based on our empirical analysis, we found two measures that have a statistically significant impact on an individual's health (the number of strong ties and the amount of conflict in the household). However, in the context of unemployment, the relevance of social integration does not seem to be as high as the literature has often suggested.

Regarding policy conclusions, according to our results, policy measures focusing exclusively on enhancing social integration are therefore unlikely to have direct positive effects on the mental health of the unemployed. However, there might be indirect effects on health if the informational, material or emotional social support provided by the social network led to re-employment. Furthermore, there might 
be especially vulnerable subgroups among the unemployed, which do profit from social integration, even if the general population of the unemployed does not. Further research should focus on identifying such subgroups.

Regarding the question of what the actual pathways are that lead to health deterioration and what factors might actually buffer against adverse health effects, the present study can only provide a few guidelines. First, at least in the German context, the loss of the manifest function of employment plays only a marginal role. We found no indication of an indirect effect via the unemployed s diminished household income. However, household income might not be a perfect measure of the manifest function of work, and other indicators, such as relative deprivation or poverty, should be considered in future research. As for status loss as an alternative explanation, although the paper by Krug and Eberl (2018) found empirical evidence for an indirect effect via the loss of subjective social status, the paper left open the degree to which this measure not only reflects the unemployed`s self-esteem but also reflects external status attributions and is thus a reaction to experiences with their immediate social environment or society as a whole. In short, we have aimed to contribute to understanding the role of social integration, but given the long tradition of empirical research, many questions regarding alternative pathways or buffering factors surprisingly remain open and await further empirical investigation. 


\section{Literature}

Åslund, Cecilia; Starrin, Bengt; Nilsson, Kent W. (2014): Psychosomatic symptoms and low psychological well-being in relation to employment status: the influence of social capital in a large cross-sectional study in Sweden. International Journal for Equity in Health, 13(1), 22.

Atkinson, Thomas; Liem, Ramsay; Liem, Joan H. (1986): The social costs of unemployment: Implications of social support. Journal of Health and Social Behavior, 27, 317-331.

Axelsson, Lars; Ejlertsson, Göran (2002): Self-reported health, self-esteem and social support among young unemployed people: A population-based study. International Journal of Social Welfare, 11, $111-119$.

Baron, Reuben M.; Kenny, David A. (1986): The moderator-mediator variable distinction in social psychological research: Conceptual, strategic, and statistical considerations. Journal of Personality and Social Psychology, 51(6), 1173-1182.

Berkman, Lisa F.; Glass, Thomas; Brisette, Ian; Seeman, Teresa E. (2000): From social integration to health: Durkheim in the new millennium. Social Sciences \& Medicine, 51(6), 843-857.

Bethmann, Arne; Fuchs, Benjamin; Wurdack, Anja (eds) (2013): User guide "Panel Study Labour Market and Social Security" (PASS) wave 6. FDZ Datenreport, 07, 112.

Böckerman, Petri; Ilmakunnas, Pekka (2009): Unemployment and self-assessed health: evidence from panel data. Health Economics, 18, 161-179.

Brand, Jennie E. (2015): The far-reaching impact of job loss and unemployment. Annual Review of Sociology, 41, 359-375.

Brüderl, Josef; Ludwig, Volker (2015): Fixed-effects panel regression. The Sage Handbook of Regression Analysis and Causal Inference, 327-357.

Burt, Ronald S. (1984): Network items and the general social survey. Social Networks, 6, 293-339.

Cassel, John (1976): The contribution of the social environment to host resistance. American Journal of Epidemiology. 104(2), 107-123.

Cheak-Zamora, Nancy C.; Wyrwich, Kathleen W. ; McBride, Timothy D. (2009): Reliability and validity of the SF-12v2 in the medical expenditure panel survey. Quality of Life Research, 18(6), $727-735$.

Cobb, Sidney (1976): Social support as a moderator of life stress. Psychosomatic Medicine, 38(5), $300-314$.

Cohen, Sheldon (2004): Social relationships and health. American Psychologist, 59(8), 676-684. 
Cygan-Rehm, Kamila; Kuehnle, Daniel; Oberfichtner, Michael (2017): Bounding the causal effect of unemployment on mental health: Nonparametric evidence from four countries. Health Economics, 1-18.

Davies, Gwenda (1996): The employment support network - an intervention to assist displaced workers. Journal of Employment Counseling, 33(4), 146-154.

Diewald, Martin (2007): Arbeitsmarktungleichheiten und die Verfügbarkeit von Sozialkapital. Die Rolle von Gratifikationen und Belastungen. In: Franzen, Axel; Freitag, Markus (eds): Sozialkapital. Theoretische Grundlagen und empirische Befunde. Kölner Zeitschrift für Soziologie und Sozialpsychologie. Sonderhefte, 47, 183-210.

Ellwardt, Lea; Wittek, Rafael P. M.; Hawkley, Louise C.; Cacioppo, John T. (2019): Social network characteristics and their associations with stress in older adults: closure and balance in a population-based sample. Journals of Gerontology: Social Sciences: series B, 12.

Faber, Ashley D.; Wasserman, Stanley (2002): Social support and social networks: synthesis and review. In: Levy, Judith A.; Pescosolido, Bernice A. (eds.): Social Networks and Health. Emerald Group Publishing Limited, 29-72.

Gallie, Duncan; Kostova, Dobrinka; Kuchar, Pavel (2001): Social consequences of unemployment: An East-West comparison. Journal of European Social Policy, 11, 39-54.

Gallie, Duncan; Paugam, Serge; Jacobs, Sheila (2003): Unemployment, poverty and social isolation: Is there a vicious circle of social exclusion? European Societies, 5(1), 1-32.

Gebel, Michael; Voßemer, Jonas (2014): The impact of employment transitions on health in Germany: A difference-in-differences propensity score matching approach. Social Science \& Medicine, 108, $128-136$.

Gore, Susan (1978): The effect of social support in moderating the health consequences of unemployment, Journal of Health and Social Behavior, 19(2), 157-165.

Granovetter, Mark S. (1973): The strength of weak ties. American Journal of Sociology, 78(6), 13601380.

Gunasekara, Fiona I.; Richardson, Ken; Carter, Kristie; Blakely, Tony (2014): Fixed effects analysis of repeated measures data. International Journal of Epidemiology, 43(1), 264-269.

Halaby, Charles N. (2004): Panel models in sociological research: Theory into practice. Annual Review of Sociology, 30, 507-544.

Hollederer, Alfons (2018): Health promotion and prevention among the unemployed: a systematic review. Health Promotion International, 1-19. 
Jahoda, Marie (1981): Work, employment, and unemployment: values, theories, and approaches in social research. American psychologist, 36(2), 184-191.

Jahoda, Marie (1982): Employment and unemployment: a social-psychological analysis. Cambridge: Cambridge University Press.

Janlert, Urban; Hammarström, Anne (2009): Which theory is best? Explanatory models of the relationship between unemployment and health. BMC Public Health, 9, 9.

Jones, Loring (1988): Unemployment and social integration: a review. The Journal of Sociology \& Social Welfare 15(4), 161-176.

Kessler, Ronald C.; Turner, J. Blake; House, James S. (1987): Intervening processes in the relationship between unemployment and health. Psychological Medicine, 17, 946-961.

Kessler, Ronald C.; Turner, J. Blake; House, James S. (1988): Effect of unemployment on health in a community survey: main, modifying, and mediating effects. Journal of Social Issues, 44(4), 6985.

Klärner, Andreas; Knabe, André (2016): Soziale Netzwerke als Ressource für den Umgang mit Langzeitarbeitslosigkeit. WSI Mitteilungen, 5, 353-364.

Klärner, Andreas; Gamper, Markus; Keim, Sylvia; Moor, Irene; von der Lippe, Holger; Vonneilich, Nico (eds.) (2019): Soziale Netzwerke und gesundheitliche Ungleichheiten: Eine neue Perspektive für die Forschung. Wiesbaden: VS Verlag für Sozialwissenschaften. In press.

Kong, Fanying; Perucci, Carolyn C.; Perucci, Robert (1993): The impact of unemployment and economic stress on social support. Community Mental Health Journal, 29(3), 205-221.

Krug, Gerhard; Eberl, Andreas (2018): What explains the negative effect of unemployment on health? An analysis accounting for reverse causality. Research in Social Stratification and Mobility, 55, $25-39$.

Mayerl, Jochen; Urban, Dieter (2019): Be cautious when estimating regression models with interaction variables: the scaling of independent variables may determine the size, direction, and significance of regression coefficients. Kölner Zeitschrift für Soziologie und Sozialpsychologie, 71(1), 135156.

Milner, Allison; Krnjacki, Lauren; Butterworth, Peter; LaMontagne, Anthony D. (2016): The role of social support in protecting mental health when employed and unemployed: a longitudinal fixedeffects analysis using 12 annual waves of the HILDA cohort. Social Science \& Medicine, 153, 20-26. 
Moore, T. H. M.; Kapur, N.; Hawton, K.; Richards, A.; Metcalfe, C.; Gunnell, D. (2017):

Interventions to reduce the impact of unemployment and economic hardship on mental health in the general population: a systematic review. Psychological medicine, 47(6), 1062-1084.

Paugam, Serge; Russell, Helen (2000): The effects of employment precarity and unemployment on social isolation. In: Gallie, Duncan; Paugam, Serge (eds.): Welfare regimes and the experience of unemployment in Europe. Oxford: Oxford UP, 243-264.

Paul, Karsten I.; Moser, Klaus (2009): Unemployment impairs mental health: Meta-analyses. Journal of Vocational Behavior, 74(3), 264-282.

Pearlin, Leonard I. (1989): The sociological study of stress. Journal of Health and Social Behavior, 30(3), 241-256.

Rantakeisu, Ulla; Starrin, Bengt; Hagquist, Curt (1999): Financial hardship and shame: A tentative model to understand the social and health effects of unemployment. The British Journal of Social Work, 29(6), 877-901.

Roodman, David (2009): How to do xtabond2: An introduction to difference and system GMM in Stata. The Stata Journal, 9(1), 86-136.

Sattler, Sebastian; Diewald, Martin (2010): Wechselwirkungen zwischen Arbeitslosigkeit und sozialen Netzwerken. In: Stegbauer, Christian; Häußling, Roger (eds.): Handbuch Netzwerkforschung. Wiesbaden: VS Verlag, 695-707.

Schmitz, Hendrik (2011): Why are the unemployed in worse health? The causal effect of unemployment on health. Labour Economics, 18(1), 71-78.

Schwarzer, R.; Jerusalem, M.; Hahn, A. (1994). Unemployment, social support and health complaints. A longitudinal study of stress in East German refugees. Journal of Community \& Applied Social Psychology, 4(1), 31-45.

Shor, Eran; Roelfs, David J.; Yogev, Tamar (2013): The strength of family ties: A meta-analysis and meta-regression of self-reported social support and mortality. Social Networks, 35, 626-638.

Smith, Kirsten P.; Christakis, Nicholas A. (2008): Social networks and health. Annual Review of Sociology, 34, 405-429.

Sobel, Michael E. (1982): Asymptotic confidence intervals for indirect effects in structural equation models. Sociological Methodology, 13, 290-312.

Stauder, Johannes (2019): Unemployment, unemployment duration, and health: Selection or causation? The European Journal of Health Economics, 20(1), 59-73. 
Thoits, Peggy A. (1982): Conceptual, methodological, and theoretical problems in studying social support as a buffer against life stress. Journal of Health and Social Behavior, 23(2), 145-159.

Thoits, Peggy A. (2011): Mechanisms linking social ties and support to physical and mental health. Journal of Health and Social Behavior, 52(2), 145-161.

Trappmann, Mark; Beste, Jonas; Bethmann, Arne; Müller, Gerrit (2013): The PASS panel survey after six waves. Journal of Labour Market Research, 46(4), 275-281.

Uchino, Bert N. (2004): Social support and physical health: Understanding the health consequences of relationships. New Haven and London: Yale University Press.

Uchino, Bert N. (2009): Understanding the links between social support and physical health: A lifespan perspective with emphasis on the separability of perceived and received support. Perspectives on Psychology Science, 4(3), 236-255.

Umberson, Debra; Crosnoe, Robert; Reczek, Corinne (2010): Social relationships and health behaviour across life course. Annual Review of Sociology, 36, 139-157.

Van der Gaag, Martin; Snijders, Tom A. B. (2005): The resource generator: social capital quantification with concrete items. Social Networks, 27(1), 1-29.

Warr, Peter (1987): Work, unemployment, and mental health. New York, NY, US: Oxford University Press.

Wellman, Barry (1981): Applying network analysis to the study of support. Social networks and social support, 4, 171-200.

Wethington, Elaine; Kessler, Ronald C. (1986): Perceived Support, Received Support, and Adjustment to Stressful Life Events. Journal of Health and Social Behavior, 27(1), 78-89.

Wilcock, Richard C.; Franke, Walter H. (1963). Unwanted workers: Permanent layoffs and long-term unemployment. Free Press of Glencoe.

Wolf, Christof (2009): Netzwerke und soziale Unterstützung: Der Vorschlag eines Moduls für die Panelerhebung „Arbeitsmarkt und soziale Sicherung“ des IAB. GESIS-Working Papers 9, 64.

Wu, Amery D.; Zumbo, Bruno D. (2008): Understanding and using mediators and moderators. Social Indicator Research, 87(3), 367-392. 


\section{Appendix}

Table A1: Operationalization of social integration

\begin{tabular}{|c|c|c|}
\hline Variable & Survey Questions & Waves \\
\hline Weak ties & $\begin{array}{l}\text { Active memberships in voluntary organizations' }(0-5) \text {; Q: } \\
\text { "Are you actively engaged in one of the following } \\
\text { organizations or associations?"; categories: union, political } \\
\text { party, church community, clubs, another organization }\end{array}$ & $1-10$ \\
\hline Strong ties & $\begin{array}{l}\text { Number of close friends or family members outside the } \\
\text { household (log; Q: "How many close friends or family } \\
\text { members, with whom you have a close relationship, do you } \\
\text { have outside your household?" }\end{array}$ & $1-10$ \\
\hline $\begin{array}{l}\text { Tensions and } \\
\text { conflicts }\end{array}$ & $\begin{array}{l}\text { Q: "How often do misunderstandings, tensions or conflicts } \\
\text { occur in your household?"; categories: very often (0), often } \\
\text { (1), sometimes (2), rarely (3), very rarely or never (4); persons } \\
\text { living in single households were excluded from this question }\end{array}$ & $1-10$ \\
\hline $\begin{array}{l}\text { Employed } \\
\text { confidants }\end{array}$ & $\begin{array}{l}\text { Number of very close confidants }(0-3 \text {; "most important", } \\
\text { "second most important" and "third most important" people } \\
\text { outside the household) working full time or part time or in a } \\
\text { vocational training; collected with a name generator }\end{array}$ & 3,5 \\
\hline $\begin{array}{l}\text { General social } \\
\text { support }\end{array}$ & $\begin{array}{l}\text { Six-point scale based on the following items: "Do you know } \\
\text { someone... } \\
\text { - } \quad \text { who's advice you can trust? } \\
\text { - } \quad \text { you can turn to with personal problems? } \\
\text { - } \quad \text { who would help you fill out forms for agencies, taxes or } \\
\text { - } \quad \text { whocial benefits? } \\
\text { - } \quad \text { who would borrow you } 1.000 \text { euro? } \\
\text { - } \quad \text { who would help you in a conflict with a family member?" }\end{array}$ & 3,5 \\
\hline $\begin{array}{l}\text { Job search social } \\
\text { support }\end{array}$ & $\begin{array}{l}\text { Four-point scale based on the following items: "Do you know } \\
\text { someone... } \\
\text { - } \quad \text { who would point out a job vacancy to you? } \\
\text { - } \quad \text { who encourages you to continue your education? } \\
\text { - } \quad \text { who would help you to apply for a job? } \\
\text { - } \quad \text { who would recommend you to an employer?" }\end{array}$ & $3,5,9$ \\
\hline
\end{tabular}


Table A2: Partial correlations of social integration variables

\begin{tabular}{|l|c|c|c|c|c|}
\hline & $\begin{array}{c}\text { Weak } \\
\text { ties }\end{array}$ & Strong ties & $\begin{array}{c}\text { Tensions and } \\
\text { conflicts }\end{array}$ & $\begin{array}{c}\text { Number of } \\
\text { employed } \\
\text { confidants }\end{array}$ & $\begin{array}{c}\text { General } \\
\text { social } \\
\text { support }\end{array}$ \\
\hline Strong ties & 0.114 & --- & --- & --- & --- \\
\hline Tensions and conflicts & -0.012 & 0.056 & --- & --- & --- \\
\hline Number of employed confidants & 0.043 & 0.329 & 0.010 & --- & -- \\
\hline General social support & 0.045 & 0.221 & 0.042 & 0.100 & -- \\
\hline Job search social support & 0.070 & 0.076 & -0.061 & 0.056 & 0.546 \\
\hline $\begin{array}{l}\text { Data source: Panel "Labour Market and Social Security" (wave 3, N=8,397); own calculations. } \\
\text { Note: Each coefficient displays the correlation of two social integration variables net of the correlation with the } \\
\text { other social integration variables. }\end{array}$ \\
\hline
\end{tabular}


Table A3: Descriptive statistics

\begin{tabular}{|c|c|c|c|c|c|c|c|c|c|c|c|c|c|c|c|c|c|}
\hline \multicolumn{2}{|l|}{ Waves } & \multicolumn{4}{|c|}{1 to 10} & \multicolumn{4}{|c|}{1 to 10 (w/o single-person $\mathrm{HH}$ ) } & \multicolumn{4}{|c|}{3 and 5} & \multicolumn{4}{|c|}{3,5 and 9} \\
\hline Variable & & Mean & $S d$ & Min & $\operatorname{Max}$ & Mean & $S d$ & Min & $\operatorname{Max}$ & Mean & $S d$ & Min & $\operatorname{Max}$ & Mean & $S d$ & Min & $\operatorname{Max}$ \\
\hline Mental health & $\begin{array}{l}\text { overall } \\
\text { between } \\
\text { within }\end{array}$ & 3.807 & $\begin{array}{l}1.244 \\
0.978 \\
0.819 \\
\end{array}$ & $\begin{array}{c}1 \\
1 \\
0.207 \\
\end{array}$ & $\begin{array}{c}5 \\
5 \\
7.093 \\
\end{array}$ & 3.859 & $\begin{array}{l}1.212 \\
0.951 \\
0.804 \\
\end{array}$ & $\begin{array}{c}1 \\
1 \\
0.259 \\
\end{array}$ & $\begin{array}{c}5 \\
5 \\
7.109 \\
\end{array}$ & 3.852 & $\begin{array}{l}1.229 \\
1.040 \\
0.655 \\
\end{array}$ & $\begin{array}{c}1 \\
1 \\
1.852 \\
\end{array}$ & $\begin{array}{c}5 \\
5 \\
5.852 \\
\end{array}$ & 3.853 & $\begin{array}{l}1.218 \\
0.995 \\
0.719 \\
\end{array}$ & $\begin{array}{c}1 \\
1 \\
1.186 \\
\end{array}$ & $\begin{array}{c}5 \\
5 \\
6.520 \\
\end{array}$ \\
\hline Employment status: employed & $\begin{array}{l}\text { overall } \\
\text { between } \\
\text { within } \\
\end{array}$ & 0.510 & $\begin{array}{l}0.500 \\
0.436 \\
0.255 \\
\end{array}$ & $\begin{array}{c}0 \\
0 \\
-0.390 \\
\end{array}$ & $\begin{array}{c}1 \\
1 \\
1.410 \\
\end{array}$ & 0.541 & $\begin{array}{l}0.498 \\
0.441 \\
0.250 \\
\end{array}$ & $\begin{array}{c}0 \\
0 \\
-0.359 \\
\end{array}$ & $\begin{array}{c}1 \\
1 \\
1.441 \\
\end{array}$ & 0.547 & $\begin{array}{l}0.498 \\
0.458 \\
0.194 \\
\end{array}$ & $\begin{array}{c}0 \\
0 \\
0.047 \\
\end{array}$ & $\begin{array}{c}1 \\
1 \\
1.047 \\
\end{array}$ & 0.567 & $\begin{array}{l}0.496 \\
0.440 \\
0.235 \\
\end{array}$ & \begin{tabular}{|c|}
0 \\
0 \\
-0.100 \\
\end{tabular} & $\begin{array}{c}1 \\
1 \\
1.234 \\
\end{array}$ \\
\hline Employment status: unemployed & \begin{tabular}{|l|} 
overall \\
between \\
within \\
\end{tabular} & 0.276 & $\begin{array}{l}0.447 \\
0.388 \\
0.247 \\
\end{array}$ & $\begin{array}{c}0 \\
0 \\
-0.624 \\
\end{array}$ & $\begin{array}{c}1 \\
1 \\
1.176 \\
\end{array}$ & 0.225 & $\begin{array}{l}0.418 \\
0.364 \\
0.233 \\
\end{array}$ & $\begin{array}{c}0 \\
0 \\
-0.675 \\
\end{array}$ & $\begin{array}{c}1 \\
1 \\
1.125 \\
\end{array}$ & 0.288 & $\begin{array}{l}0.453 \\
0.409 \\
0.195 \\
\end{array}$ & $\begin{array}{c}0 \\
0 \\
-0.212 \\
\end{array}$ & $\begin{array}{c}1 \\
1 \\
0.788 \\
\end{array}$ & 0.263 & $\begin{array}{l}0.440 \\
0.386 \\
0.222 \\
\end{array}$ & \begin{tabular}{|c|}
0 \\
0 \\
-0.403 \\
\end{tabular} & $\begin{array}{c}1 \\
1 \\
0.930\end{array}$ \\
\hline $\begin{array}{l}\text { Employment status: out of labor } \\
\text { force }\end{array}$ & \begin{tabular}{|l|} 
overall \\
between \\
within \\
\end{tabular} & 0.214 & $\begin{array}{l}0.410 \\
0.367 \\
0.224 \\
\end{array}$ & $\begin{array}{c}0 \\
0 \\
-0.686 \\
\end{array}$ & $\begin{array}{c}1 \\
1 \\
1.114 \\
\end{array}$ & 0.234 & $\begin{array}{l}0.424 \\
0.380 \\
0.227 \\
\end{array}$ & $\begin{array}{c}0 \\
0 \\
-0.666 \\
\end{array}$ & $\begin{array}{c}1 \\
1 \\
1.134 \\
\end{array}$ & 0.165 & $\begin{array}{l}0.371 \\
0.338 \\
0.154 \\
\end{array}$ & $\begin{array}{c}0 \\
0 \\
-0.335 \\
\end{array}$ & $\begin{array}{c}1 \\
1 \\
0.665 \\
\end{array}$ & 0.170 & $\begin{array}{l}0.375 \\
0.329 \\
0.194 \\
\end{array}$ & \begin{tabular}{|c|}
0 \\
0 \\
-0.497 \\
\end{tabular} & $\begin{array}{c}1 \\
1 \\
0.836 \\
\end{array}$ \\
\hline Weak ties & $\begin{array}{l}\text { overall } \\
\text { between } \\
\text { within }\end{array}$ & 0.582 & $\begin{array}{l}0.792 \\
0.656 \\
0.422 \\
\end{array}$ & $\begin{array}{c}0 \\
0 \\
-2.085 \\
\end{array}$ & $\begin{array}{c}5 \\
5 \\
4.382 \\
\end{array}$ & --- & --- & --- & --- & --- & --- & --- & --- & --- & --- & --- & --- \\
\hline Strong ties & \begin{tabular}{|l|} 
overall \\
between \\
within \\
\end{tabular} & 1.833 & $\begin{array}{l}0.767 \\
0.633 \\
0.478 \\
\end{array}$ & $\begin{array}{c}0 \\
0 \\
-1.232 \\
\end{array}$ & $\begin{array}{l}4.605 \\
4.600 \\
4.807 \\
\end{array}$ & --- & --- & --- & --- & --- & --- & --- & --- & --- & --- & --- & --- \\
\hline Tensions and conflicts & \begin{tabular}{|l|} 
overall \\
between \\
within \\
\end{tabular} & --- & --- & --- & --- & 2.486 & $\begin{array}{l}0.977 \\
0.777 \\
0.622 \\
\end{array}$ & $\begin{array}{c}0 \\
0 \\
-1.069 \\
\end{array}$ & $\begin{array}{c}4 \\
4 \\
5.708 \\
\end{array}$ & --- & --- & --- & --- & --- & --- & --- & --- \\
\hline Number of employed confidants & \begin{tabular}{|l} 
overall \\
between \\
within \\
\end{tabular} & --- & --- & --- & --- & --- & --- & --- & --- & 1.657 & $\begin{array}{l}1.027 \\
0.866 \\
0.552 \\
\end{array}$ & $\begin{array}{c}0 \\
0 \\
0.157 \\
\end{array}$ & $\begin{array}{c}3 \\
3 \\
3.157 \\
\end{array}$ & --- & --- & --- & --- \\
\hline General social support & $\begin{array}{l}\text { overall } \\
\text { between } \\
\text { within } \\
\end{array}$ & --- & --- & --- & --- & --- & --- & --- & --- & 5.268 & $\begin{array}{l}1.256 \\
1.097 \\
0.613 \\
\end{array}$ & $\begin{array}{c}0 \\
0 \\
2.268 \\
\end{array}$ & $\begin{array}{c}6 \\
6 \\
8.268 \\
\end{array}$ & --- & --- & --- & --- \\
\hline Job search social support & $\begin{array}{l}\text { overall } \\
\text { between } \\
\text { within } \\
\end{array}$ & --- & --- & --- & --- & --- & --- & --- & --- & --- & --- & --- & --- & 3.368 & $\begin{array}{l}1.115 \\
0.936 \\
0.632 \\
\end{array}$ & \begin{tabular}{|c|}
0 \\
0 \\
0.702 \\
\end{tabular} & $\begin{array}{c}4 \\
4 \\
6.035 \\
\end{array}$ \\
\hline $\begin{array}{l}\text { General-education and vocational } \\
\text { school (years) }\end{array}$ & $\begin{array}{l}\text { overall } \\
\text { between } \\
\text { within } \\
\end{array}$ & 12.043 & $\begin{array}{l}2.696 \\
2.656 \\
0.332 \\
\end{array}$ & $\begin{array}{c}7 \\
7 \\
6.043 \\
\end{array}$ & $\begin{array}{c}21 \\
21 \\
18.043 \\
\end{array}$ & 12.018 & $\begin{array}{l}2.680 \\
2.640 \\
0.321 \\
\end{array}$ & $\begin{array}{c}7 \\
7 \\
6.018 \\
\end{array}$ & $\begin{array}{c}21 \\
21 \\
16.733 \\
\end{array}$ & 12.203 & $\begin{array}{l}2.709 \\
2.701 \\
0.208 \\
\end{array}$ & $\begin{array}{c}7 \\
7 \\
9.703 \\
\end{array}$ & \begin{tabular}{|c|}
21 \\
21 \\
14.703 \\
\end{tabular} & 12.253 & $\begin{array}{l}2.720 \\
2.708 \\
0.271 \\
\end{array}$ & $\begin{array}{c}7 \\
7 \\
7.919 \\
\end{array}$ & $\begin{array}{c}21 \\
21 \\
16.253 \\
\end{array}$ \\
\hline Work experience (months) & \begin{tabular}{|l|} 
overall \\
between \\
within \\
\end{tabular} & 200.821 & \begin{tabular}{|c|}
154.687 \\
157.147 \\
17.952 \\
\end{tabular} & $\begin{array}{c}0 \\
0 \\
-127.179 \\
\end{array}$ & \begin{tabular}{|c|}
814 \\
809.667 \\
598.321 \\
\end{tabular} & 199.411 & $\begin{array}{c}154.067 \\
155.852 \\
18.279 \\
\end{array}$ & $\begin{array}{c}0 \\
0 \\
-128.589 \\
\end{array}$ & \begin{tabular}{|c|}
637 \\
626.333 \\
596.911 \\
\end{tabular} & 208.342 & $\begin{array}{c}147.382 \\
147.115 \\
8.991 \\
\end{array}$ & $\begin{array}{c}0 \\
0 \\
189.842 \\
\end{array}$ & \begin{tabular}{|c|}
603 \\
590.000 \\
226.842 \\
\end{tabular} & 217.014 & $\begin{array}{c}147.462 \\
147.566 \\
19.901 \\
\end{array}$ & \begin{tabular}{|c|}
0 \\
0 \\
29.514 \\
\end{tabular} & $\begin{array}{c}622 \\
590.000 \\
514.680 \\
\end{array}$ \\
\hline $\begin{array}{l}\text { Previous unemployment } \\
\text { experience (yes/no) }\end{array}$ & $\begin{array}{l}\text { overall } \\
\text { between } \\
\text { within }\end{array}$ & 0.720 & $\begin{array}{l}0.449 \\
0.442 \\
0.087\end{array}$ & $\begin{array}{c}0 \\
0 \\
-0.180 \\
\end{array}$ & $\begin{array}{c}1 \\
1 \\
1.620 \\
\end{array}$ & 0.676 & $\begin{array}{l}0.468 \\
0.459 \\
0.093\end{array}$ & $\begin{array}{c}0 \\
0 \\
-0.224 \\
\end{array}$ & $\begin{array}{c}1 \\
1 \\
1.576 \\
\end{array}$ & 0.733 & $\begin{array}{l}0.442 \\
0.440 \\
0.047\end{array}$ & $\begin{array}{c}0 \\
0 \\
0.233 \\
\end{array}$ & $\begin{array}{c}1 \\
1 \\
1.233 \\
\end{array}$ & 0.735 & $\begin{array}{l}0.442 \\
0.436 \\
0.054 \\
\end{array}$ & \begin{tabular}{|c|}
0 \\
0 \\
0.068 \\
\end{tabular} & $\begin{array}{c}1 \\
1 \\
1.401 \\
\end{array}$ \\
\hline
\end{tabular}




\begin{tabular}{|c|c|c|c|c|c|c|c|c|c|c|c|c|c|c|c|c|c|}
\hline Number of own children & \begin{tabular}{|l|} 
overall \\
between \\
within
\end{tabular} & 1.442 & $\begin{array}{l}.311 \\
1.281 \\
0.362\end{array}$ & $\begin{array}{c}0 \\
0 \\
-3.891\end{array}$ & $\begin{array}{c}16 \\
12 \\
9.220\end{array}$ & 1.651 & $\begin{array}{l}1.291 \\
1.271 \\
0.372\end{array}$ & $\begin{array}{c}0 \\
0 \\
-3.683\end{array}$ & $\begin{array}{c}16 \\
12 \\
9.428\end{array}$ & 1.461 & $\begin{array}{l}1.268 \\
1.233 \\
0.296\end{array}$ & $\begin{array}{c}0 \\
0 \\
-1.039\end{array}$ & $\begin{array}{c}10 \\
9.5 \\
3.961\end{array}$ & 1.484 & $\begin{array}{l}1.265 \\
1.231 \\
0.336\end{array}$ & \begin{tabular}{|c|}
0 \\
0 \\
-1.849
\end{tabular} & $\begin{array}{c}10 \\
9.5 \\
3.984\end{array}$ \\
\hline Household size & \begin{tabular}{|l|} 
overall \\
between \\
within \\
\end{tabular} & 2.604 & $\begin{array}{l}1.363 \\
1.325 \\
0.429 \\
\end{array}$ & $\begin{array}{c}1 \\
1 \\
-1.562 \\
\end{array}$ & $\begin{array}{c}11 \\
10.333 \\
8.271 \\
\end{array}$ & 3.092 & $\begin{array}{l}1.188 \\
1.152 \\
0.393 \\
\end{array}$ & $\begin{array}{c}2 \\
2 \\
-1.074\end{array}$ & $\begin{array}{c}11 \\
10.333 \\
8.759\end{array}$ & 2.602 & $\begin{array}{l}1.346 \\
1.311 \\
0.303\end{array}$ & $\begin{array}{c}1 \\
1 \\
0.102\end{array}$ & $\begin{array}{c}10 \\
10.000 \\
5.102\end{array}$ & 2.577 & $\begin{array}{l}1.339 \\
1.285 \\
0.407\end{array}$ & $\begin{array}{c}1 \\
1 \\
-0.756\end{array}$ & $\begin{array}{c}10 \\
10.000 \\
5.577\end{array}$ \\
\hline Age $<25$ & \begin{tabular}{|l|} 
overall \\
between \\
within
\end{tabular} & 0.080 & $\begin{array}{l}0.271 \\
0.294 \\
0.114 \\
\end{array}$ & $\begin{array}{c}0 \\
0 \\
-0.795\end{array}$ & $\begin{array}{c}1 \\
1 \\
0.980\end{array}$ & 0.085 & $\begin{array}{l}0.279 \\
0.306 \\
0.109\end{array}$ & $\begin{array}{c}0 \\
0 \\
-0.790\end{array}$ & $\begin{array}{c}1 \\
1 \\
0.985\end{array}$ & 0.050 & $\begin{array}{l}0.218 \\
0.203 \\
0.080\end{array}$ & $\begin{array}{c}0 \\
0 \\
-0.450\end{array}$ & $\begin{array}{c}1 \\
1 \\
0.550\end{array}$ & 0.039 & $\begin{array}{l}0.193 \\
0.175 \\
0.099\end{array}$ & \begin{tabular}{|c|}
0 \\
0 \\
-0.628 \\
\end{tabular} & $\begin{array}{c}1 \\
1 \\
0.706 \\
\end{array}$ \\
\hline Age $25-34$ & \begin{tabular}{|l|} 
overall \\
between \\
within
\end{tabular} & 0.191 & $\begin{array}{l}0.393 \\
0.372 \\
0.182 \\
\end{array}$ & $\begin{array}{c}0 \\
0 \\
-0.709\end{array}$ & $\begin{array}{c}1 \\
1 \\
1.091 \\
\end{array}$ & 0.191 & $\begin{array}{l}0.393 \\
0.373 \\
0.182 \\
\end{array}$ & $\begin{array}{c}0 \\
0 \\
-0.709\end{array}$ & $\begin{array}{c}1 \\
1 \\
1.091\end{array}$ & 0.178 & $\begin{array}{l}0.383 \\
0.360 \\
0.129\end{array}$ & $\begin{array}{c}0 \\
0 \\
-0.322\end{array}$ & $\begin{array}{c}1 \\
1 \\
0.678 \\
\end{array}$ & 0.164 & $\begin{array}{l}0.370 \\
0.331 \\
0.174 \\
\end{array}$ & \begin{tabular}{|c|}
0 \\
0 \\
-0.503 \\
\end{tabular} & $\begin{array}{c}1 \\
1 \\
0.830 \\
\end{array}$ \\
\hline Age $35-44$ & \begin{tabular}{|l|} 
overall \\
between \\
within \\
\end{tabular} & 0.226 & $\begin{array}{l}0.418 \\
0.365 \\
0.224 \\
\end{array}$ & $\begin{array}{c}0 \\
0 \\
-0.674 \\
\end{array}$ & $\begin{array}{c}1 \\
1 \\
1.126 \\
\end{array}$ & 0.243 & $\begin{array}{l}0.429 \\
0.373 \\
0.229 \\
\end{array}$ & $\begin{array}{c}0 \\
0 \\
-0.657 \\
\end{array}$ & $\begin{array}{c}1 \\
1 \\
1.143 \\
\end{array}$ & 0.262 & $\begin{array}{l}0.440 \\
0.407 \\
0.167 \\
\end{array}$ & $\begin{array}{c}0 \\
0 \\
-0.238 \\
\end{array}$ & $\begin{array}{c}1 \\
1 \\
0.762 \\
\end{array}$ & 0.248 & $\begin{array}{l}0.432 \\
0.367 \\
0.234 \\
\end{array}$ & \begin{tabular}{|c|}
0 \\
0 \\
-0.419 \\
\end{tabular} & $\begin{array}{c}1 \\
1 \\
0.914 \\
\end{array}$ \\
\hline Age $45-54$ & \begin{tabular}{|l} 
overall \\
between \\
within \\
\end{tabular} & 0.277 & $\begin{array}{l}0.447 \\
0.379 \\
0.246 \\
\end{array}$ & $\begin{array}{c}0 \\
0 \\
-0.623 \\
\end{array}$ & $\begin{array}{c}1 \\
1 \\
1.177 \\
\end{array}$ & 0.279 & $\begin{array}{l}0.448 \\
0.381 \\
0.244 \\
\end{array}$ & $\begin{array}{c}0 \\
0 \\
-0.621 \\
\end{array}$ & $\begin{array}{c}1 \\
1 \\
1.179 \\
\end{array}$ & 0.295 & $\begin{array}{l}0.456 \\
0.418 \\
0.181 \\
\end{array}$ & $\begin{array}{c}0 \\
0 \\
-0.205 \\
\end{array}$ & $\begin{array}{c}1 \\
1 \\
0.795 \\
\end{array}$ & 0.311 & $\begin{array}{l}0.463 \\
0.385 \\
0.262 \\
\end{array}$ & \begin{tabular}{|c|}
0 \\
0 \\
-0.355 \\
\end{tabular} & $\begin{array}{c}1 \\
1 \\
0.978 \\
\end{array}$ \\
\hline Age $55-64$ & \begin{tabular}{|l} 
overall \\
between \\
within \\
\end{tabular} & 0.226 & $\begin{array}{l}0.418 \\
0.382 \\
0.174 \\
\end{array}$ & $\begin{array}{c}0 \\
0 \\
-0.674 \\
\end{array}$ & $\begin{array}{c}1 \\
1 \\
1.126 \\
\end{array}$ & 0.203 & $\begin{array}{l}0.402 \\
0.367 \\
0.168 \\
\end{array}$ & $\begin{array}{c}0 \\
0 \\
-0.697 \\
\end{array}$ & $\begin{array}{c}1 \\
1 \\
1.103 \\
\end{array}$ & 0.214 & $\begin{array}{l}0.410 \\
0.391 \\
0.124 \\
\end{array}$ & $\begin{array}{c}0 \\
0 \\
-0.286 \\
\end{array}$ & $\begin{array}{c}1 \\
1 \\
0.714 \\
\end{array}$ & 0.238 & $\begin{array}{l}0.426 \\
0.391 \\
0.184 \\
\end{array}$ & \begin{tabular}{|c|}
0 \\
0 \\
-0.428 \\
\end{tabular} & $\begin{array}{c}1 \\
1 \\
0.905 \\
\end{array}$ \\
\hline $\begin{array}{l}\text { Observations } \\
\text { Persons } \\
\text { Average number of years }\end{array}$ & ervation & & $\begin{array}{l}8 \\
1 \\
4\end{array}$ & & & & $\begin{array}{l}6 \\
1 \\
-\end{array}$ & & & & & $\begin{array}{l}94 \\
47 \\
2\end{array}$ & & & & & \\
\hline
\end{tabular}


Table A4: Fixed effects regressions of social integration on unemployment (full table)

\begin{tabular}{|c|c|c|c|c|c|c|}
\hline \multirow[b]{2}{*}{ Dependent variable } & \multicolumn{3}{|c|}{ Waves $1-10$} & \multicolumn{2}{|c|}{ Waves 3 and 5} & \multirow{2}{*}{$\begin{array}{c}\text { Waves } 3,5 \text { and } 9 \\
\begin{array}{c}\text { Job search social } \\
\text { support }\end{array}\end{array}$} \\
\hline & Weak ties & Strong ties & $\begin{array}{l}\text { Tensions and } \\
\text { conflicts }^{\text {a) }}\end{array}$ & $\begin{array}{l}\text { Employed } \\
\text { confidants }\end{array}$ & $\begin{array}{c}\text { General } \\
\text { social } \\
\text { support } \\
\end{array}$ & \\
\hline & $\begin{array}{l}\text { Model } 1 \\
\text { Coef. }\end{array}$ & $\begin{array}{l}\text { Model } 2 \\
\text { Coef. }\end{array}$ & $\begin{array}{c}\text { Model } 3 \\
\text { Coef. }\end{array}$ & $\begin{array}{l}\text { Model } 4 \\
\text { Coef. }\end{array}$ & $\begin{array}{c}\text { Model } 5 \\
\text { Coef. }\end{array}$ & $\begin{array}{c}\text { Model } 6 \\
\text { Coef. }\end{array}$ \\
\hline \multicolumn{7}{|l|}{ Employment status (ref.: employed) } \\
\hline Unemployed & $\begin{array}{l}-0.008 \\
(0.008)\end{array}$ & $\begin{array}{l}-0.018 \\
(0.009)\end{array}$ & $\begin{array}{c}0.013 \\
(0.015)\end{array}$ & $\begin{array}{c}-0.139 * * \\
(0.047)\end{array}$ & $\begin{array}{c}-0.146 * * \\
(0.050)\end{array}$ & $\begin{array}{l}-0.001 \\
(0.034)\end{array}$ \\
\hline Out of labor force & $\begin{array}{c}0.017 \\
(0.010)\end{array}$ & $\begin{array}{c}0.010 \\
(0.010)\end{array}$ & $\begin{array}{l}0.038^{*} \\
(0.015)\end{array}$ & $\begin{array}{l}-0.043 \\
(0.060)\end{array}$ & $\begin{array}{l}-0.062 \\
(0.058)\end{array}$ & $\begin{array}{l}-0.059 \\
(0.038)\end{array}$ \\
\hline General-education and vocational school (years) & $\begin{array}{c}0.009 \\
(0.006)\end{array}$ & $\begin{array}{c}0.005 \\
(0.006)\end{array}$ & $\begin{array}{c}0.015 \\
(0.009)\end{array}$ & $\begin{array}{c}-0.053 \\
(0.032)\end{array}$ & $\begin{array}{l}-0.052 * \\
(0.023)\end{array}$ & $\begin{array}{l}-0.010 \\
(0.015)\end{array}$ \\
\hline Work experience (months) & $\begin{array}{l}0.000 * \\
(0.000)\end{array}$ & $\begin{array}{c}-0.001 * * * \\
(0.000)\end{array}$ & $\begin{array}{l}0.001 * \\
(0.000)\end{array}$ & $\begin{array}{c}0.001 \\
(0.001)\end{array}$ & $\begin{array}{l}-0.000 \\
(0.002)\end{array}$ & $\begin{array}{c}0.001 \\
(0.001)\end{array}$ \\
\hline Previous unemployment experience (yes/no) & $\begin{array}{c}0.020 \\
(0.023)\end{array}$ & $\begin{array}{c}0.018 \\
(0.027)\end{array}$ & $\begin{array}{c}0.003 \\
(0.037)\end{array}$ & $\begin{array}{c}0.045 \\
(0.191)\end{array}$ & $\begin{array}{l}-0.132 \\
(0.258)\end{array}$ & $\begin{array}{c}0.047 \\
(0.142)\end{array}$ \\
\hline Number of own children & $\begin{array}{c}0.002 \\
(0.005)\end{array}$ & $\begin{array}{c}0.022 * * * \\
(0.007)\end{array}$ & $\begin{array}{c}-0.007 \\
(0.009)\end{array}$ & $\begin{array}{c}0.009 \\
(0.030)\end{array}$ & $\begin{array}{c}0.019 \\
(0.038)\end{array}$ & $\begin{array}{l}-0.005 \\
(0.027)\end{array}$ \\
\hline Household size & $\begin{array}{c}0.005 \\
(0.005)\end{array}$ & $\begin{array}{c}-0.052 * * * \\
(0.005)\end{array}$ & $\begin{array}{c}-0.154 * * * \\
(0.009)\end{array}$ & $\begin{array}{l}-0.036 \\
(0.031)\end{array}$ & $\begin{array}{c}0.018 \\
(0.032)\end{array}$ & $\begin{array}{l}-0.017 \\
(0.018)\end{array}$ \\
\hline Age groups (ref.: 55-64) & & & & & & \\
\hline$<25$ & $\begin{array}{c}0.025 \\
(0.029)\end{array}$ & $\begin{array}{l}-0.004 \\
(0.033)\end{array}$ & $\begin{array}{c}0.032 \\
(0.051)\end{array}$ & $\begin{array}{l}-0.166 \\
(0.173)\end{array}$ & $\begin{array}{l}-0.116 \\
(0.184)\end{array}$ & $\begin{array}{l}-0.043 \\
(0.115)\end{array}$ \\
\hline $25-34$ & $\begin{array}{c}0.010 \\
(0.024)\end{array}$ & $\begin{array}{c}0.024 \\
(0.026)\end{array}$ & $\begin{array}{l}-0.019 \\
(0.038)\end{array}$ & $\begin{array}{l}-0.067 \\
(0.131)\end{array}$ & $\begin{array}{l}-0.061 \\
(0.147)\end{array}$ & $\begin{array}{l}-0.026 \\
(0.088)\end{array}$ \\
\hline $35-44$ & $\begin{array}{c}0.020 \\
(0.018)\end{array}$ & $\begin{array}{l}-0.022 \\
(0.019)\end{array}$ & $\begin{array}{l}-0.062^{*} \\
(0.028)\end{array}$ & $\begin{array}{l}-0.083 \\
(0.092)\end{array}$ & $\begin{array}{l}-0.089 \\
(0.110)\end{array}$ & $\begin{array}{l}-0.007 \\
(0.066)\end{array}$ \\
\hline $45-54$ & $\begin{array}{c}0.009 \\
(0.012)\end{array}$ & $\begin{array}{c}-0.039 * * \\
(0.013)\end{array}$ & $\begin{array}{l}-0.040^{*} \\
(0.019)\end{array}$ & $\begin{array}{l}-0.009 \\
(0.065)\end{array}$ & $\begin{array}{l}-0.050 \\
(0.076)\end{array}$ & $\begin{array}{c}0.030 \\
(0.046)\end{array}$ \\
\hline Within $\mathrm{R}^{2}$ & 0.006 & 0.011 & 0.019 & 0.010 & 0.015 & 0.014 \\
\hline $\begin{array}{l}\text { Observations } \\
\text { (persons) }\end{array}$ & $\begin{array}{c}89,184 \\
(19,180)\end{array}$ & $\begin{array}{c}89,184 \\
(19,180)\end{array}$ & $\begin{array}{c}67,912 \\
(15,084)\end{array}$ & $\begin{array}{c}9,894 \\
(4,947)\end{array}$ & $\begin{array}{c}9,894 \\
(4,947)\end{array}$ & $\begin{array}{l}14,188 \\
(5,656)\end{array}$ \\
\hline
\end{tabular}


Table A5: Test of the causal pathway hypothesis based on fixed effects regressions (full table)

\begin{tabular}{|c|c|c|c|c|c|c|c|c|c|c|}
\hline \multirow[b]{2}{*}{ Indicator for social integration } & \multicolumn{5}{|c|}{ Waves $1-10$} & \multicolumn{3}{|c|}{ Waves 3 and 5} & \multicolumn{2}{|c|}{ Waves 3,5 and 9} \\
\hline & --- & Weak ties & Strong ties & --- & $\begin{array}{c}\text { Tensions } \\
\text { and } \\
\text { conflicts }^{\text {a) }}\end{array}$ & --- & $\begin{array}{l}\text { Employed } \\
\text { confidants }\end{array}$ & $\begin{array}{c}\text { General } \\
\text { social } \\
\text { support }\end{array}$ & --- & $\begin{array}{c}\text { Job search } \\
\text { social } \\
\text { support }\end{array}$ \\
\hline Employment status (ref.: employed) & $\begin{array}{l}\text { Model 0.a } \\
\text { Coef. }\end{array}$ & $\begin{array}{l}\text { Model } 1 \\
\text { Coef. }\end{array}$ & $\begin{array}{c}\text { Model } 2 \\
\text { Coef. }\end{array}$ & $\begin{array}{c}\text { Model 0.b } \\
\text { Coef. }\end{array}$ & $\begin{array}{l}\text { Model } 3 \\
\text { Coef. }\end{array}$ & $\begin{array}{l}\text { Model 0.c } \\
\text { Coef. }\end{array}$ & $\begin{array}{l}\text { Model } 4 \\
\text { Coef. }\end{array}$ & $\begin{array}{l}\text { Model } 5 \\
\text { Coef. }\end{array}$ & $\begin{array}{l}\text { Model 0.d } \\
\text { Coef. }\end{array}$ & $\begin{array}{l}\text { Model } 6 \\
\text { Coef. }\end{array}$ \\
\hline Unemployed & $\begin{array}{l}-0.223 * * * \\
(0.016)\end{array}$ & $\begin{array}{l}-0.222 * * * \\
(0.016)\end{array}$ & $\begin{array}{l}-0.222 * * * \\
(0.016)\end{array}$ & $\begin{array}{c}-0.210 * * * \\
(0.019)\end{array}$ & $\begin{array}{l}-0.212 * * * \\
(0.019)\end{array}$ & $\begin{array}{l}-0.202 * * * \\
(0.056)\end{array}$ & $\begin{array}{c}-0.198 * * * \\
(0.056)\end{array}$ & $\begin{array}{c}-0.198 * * * \\
(0.057)\end{array}$ & $\begin{array}{c}-0.195 * * * \\
(0.041)\end{array}$ & $\begin{array}{c}-0.195 * * * \\
(0.041)\end{array}$ \\
\hline Out of labor force & $\begin{array}{l}-0.062 * * * \\
(0.017)\end{array}$ & $\begin{array}{c}-0.062 * * * \\
(0.017)\end{array}$ & $\begin{array}{c}-0.062 * * * \\
(0.017)\end{array}$ & $\begin{array}{c}-0.052 * * \\
(0.019)\end{array}$ & $\begin{array}{c}-0.058 * * \\
(0.019)\end{array}$ & $\begin{array}{l}-0.075 \\
(0.069)\end{array}$ & $\begin{array}{l}-0.074 \\
(0.069)\end{array}$ & $\begin{array}{l}-0.074 \\
(0.069)\end{array}$ & $\begin{array}{l}-0.062 \\
(0.047)\end{array}$ & $\begin{array}{l}-0.062 \\
(0.047)\end{array}$ \\
\hline Indicator for social integration & & $\begin{array}{c}0.005 \\
(0.008)\end{array}$ & $\begin{array}{c}0.049 * * * \\
(0.007)\end{array}$ & & $\begin{array}{c}0.147 * * * \\
(0.006)\end{array}$ & & $\begin{array}{c}0.029 \\
(0.017)\end{array}$ & $\begin{array}{c}0.025 \\
(0.017)\end{array}$ & & $\begin{array}{c}-0.001 \\
(0.013)\end{array}$ \\
\hline $\begin{array}{l}\text { General-education and vocational } \\
\text { school (years) }\end{array}$ & $\begin{array}{c}0.019 \\
(0.010)\end{array}$ & $\begin{array}{c}0.019 \\
(0.010)\end{array}$ & $\begin{array}{c}0.019 \\
(0.010)\end{array}$ & $\begin{array}{c}0.010 \\
(0.012)\end{array}$ & $\begin{array}{c}0.007 \\
(0.012)\end{array}$ & $\begin{array}{l}-0.004 \\
(0.038)\end{array}$ & $\begin{array}{l}-0.002 \\
(0.038)\end{array}$ & $\begin{array}{l}-0.003 \\
(0.038)\end{array}$ & $\begin{array}{c}0.004 \\
(0.030)\end{array}$ & $\begin{array}{c}0.004 \\
(0.030)\end{array}$ \\
\hline Work experience (months) & $\begin{array}{l}-0.001 * * * \\
(0.000)\end{array}$ & $\begin{array}{c}-0.001 * * * \\
(0.000)\end{array}$ & $\begin{array}{l}-0.001 * * * \\
(0.000)\end{array}$ & $\begin{array}{l}-0.001 * * \\
(0.000)\end{array}$ & $\begin{array}{c}-0.001 * * * \\
(0.000)\end{array}$ & $\begin{array}{c}0.001 \\
(0.002)\end{array}$ & $\begin{array}{c}0.001 \\
(0.002)\end{array}$ & $\begin{array}{c}0.001 \\
(0.002)\end{array}$ & $\begin{array}{c}0.000 \\
(0.001)\end{array}$ & $\begin{array}{c}0.000 \\
(0.001)\end{array}$ \\
\hline $\begin{array}{l}\text { Previous unemployment experience } \\
\text { (yes/no) }\end{array}$ & $\begin{array}{c}0.050 \\
(0.042)\end{array}$ & $\begin{array}{c}0.050 \\
(0.042)\end{array}$ & $\begin{array}{c}0.049 \\
(0.042)\end{array}$ & $\begin{array}{c}0.054 \\
(0.045)\end{array}$ & $\begin{array}{c}0.053 \\
(0.045)\end{array}$ & $\begin{array}{l}-0.098 \\
(0.181)\end{array}$ & $\begin{array}{l}-0.099 \\
(0.180)\end{array}$ & $\begin{array}{l}-0.094 \\
(0.179)\end{array}$ & $\begin{array}{l}-0.139 \\
(0.133)\end{array}$ & $\begin{array}{l}-0.139 \\
(0.133)\end{array}$ \\
\hline Number of own children & $\begin{array}{c}-0.032 * * \\
(0.010)\end{array}$ & $\begin{array}{c}-0.032 * * \\
(0.010)\end{array}$ & $\begin{array}{c}-0.033^{* * * *} \\
(0.010)\end{array}$ & $\begin{array}{c}-0.033 * * \\
(0.011)\end{array}$ & $\begin{array}{c}-0.032 * * \\
(0.011)\end{array}$ & $\begin{array}{c}0.007 \\
(0.038)\end{array}$ & $\begin{array}{c}0.007 \\
(0.038)\end{array}$ & $\begin{array}{c}0.007 \\
(0.038)\end{array}$ & $\begin{array}{l}-0.016 \\
(0.027)\end{array}$ & $\begin{array}{l}-0.016 \\
(0.027)\end{array}$ \\
\hline Household size & $\begin{array}{c}0.001 \\
(0.009)\end{array}$ & $\begin{array}{c}0.001 \\
(0.009)\end{array}$ & $\begin{array}{c}0.003 \\
(0.009)\end{array}$ & $\begin{array}{l}-0.021 \\
(0.011)\end{array}$ & $\begin{array}{c}0.001 \\
(0.011)\end{array}$ & $\begin{array}{c}0.000 \\
(0.034)\end{array}$ & $\begin{array}{c}0.001 \\
(0.034)\end{array}$ & $\begin{array}{l}-0.000 \\
(0.034)\end{array}$ & $\begin{array}{c}0.027 \\
(0.021)\end{array}$ & $\begin{array}{c}0.027 \\
(0.021)\end{array}$ \\
\hline Ageg & & & & & & & & & & \\
\hline$<25$ & $\begin{array}{c}0.101 \\
(0.056)\end{array}$ & $\begin{array}{c}0.100 \\
(0.056)\end{array}$ & $\begin{array}{c}0.101 \\
(0.056)\end{array}$ & $\begin{array}{c}0.027 \\
(0.063)\end{array}$ & $\begin{array}{c}0.022 \\
(0.063)\end{array}$ & $\begin{array}{l}-0.246 \\
(0.193)\end{array}$ & $\begin{array}{c}-0.241 \\
(0.194)\end{array}$ & $\begin{array}{l}-0.243 \\
(0.194)\end{array}$ & $\begin{array}{l}-0.013 \\
(0.136)\end{array}$ & $\begin{array}{l}-0.013 \\
(0.136)\end{array}$ \\
\hline $25-34$ & $\begin{array}{c}0.038 \\
(0.043)\end{array}$ & $\begin{array}{c}0.038 \\
(0.043)\end{array}$ & $\begin{array}{c}0.037 \\
(0.043)\end{array}$ & $\begin{array}{l}-0.029 \\
(0.049)\end{array}$ & $\begin{array}{l}-0.026 \\
(0.048)\end{array}$ & $\begin{array}{l}-0.294 \\
(0.153)\end{array}$ & $\begin{array}{l}-0.292 \\
(0.153)\end{array}$ & $\begin{array}{l}-0.292 \\
(0.153)\end{array}$ & $\begin{array}{l}-0.168 \\
(0.101)\end{array}$ & $\begin{array}{l}-0.168 \\
(0.101)\end{array}$ \\
\hline $35-44$ & $\begin{array}{c}0.014 \\
(0.032)\end{array}$ & $\begin{array}{c}0.014 \\
(0.032)\end{array}$ & $\begin{array}{c}0.015 \\
(0.032)\end{array}$ & $\begin{array}{l}-0.027 \\
(0.036)\end{array}$ & $\begin{array}{l}-0.018 \\
(0.036)\end{array}$ & $\begin{array}{l}-0.078 \\
(0.112)\end{array}$ & $\begin{array}{l}-0.075 \\
(0.112)\end{array}$ & $\begin{array}{l}-0.076 \\
(0.112)\end{array}$ & $\begin{array}{l}-0.087 \\
(0.072)\end{array}$ & $\begin{array}{l}-0.087 \\
(0.072)\end{array}$ \\
\hline $45-54$ & $\begin{array}{c}-0.004 \\
(0.021)\end{array}$ & $\begin{array}{c}-0.004 \\
(0.021)\end{array}$ & $\begin{array}{c}-0.002 \\
(0.021)\end{array}$ & $\begin{array}{l}-0.020 \\
(0.024)\end{array}$ & $\begin{array}{l}-0.015 \\
(0.024)\end{array}$ & $\begin{array}{c}-0.001 \\
(0.076)\end{array}$ & $\begin{array}{c}-0.001 \\
(0.076)\end{array}$ & $\begin{array}{c}0.000 \\
-0.076\end{array}$ & $\begin{array}{c}-0.064 \\
(0.045)\end{array}$ & $\begin{array}{l}-0.064 \\
(0.045)\end{array}$ \\
\hline Within $\mathrm{R}^{2}$ & 0.005 & 0.005 & 0.006 & 0.005 & 0.018 & 0.005 & 0.005 & 0.005 & 0.005 & 0.005 \\
\hline $\begin{array}{l}\text { Observations } \\
\text { (persons) }\end{array}$ & $\begin{array}{c}89,184 \\
(19,180)\end{array}$ & $\begin{array}{c}89,184 \\
(19,180)\end{array}$ & $\begin{array}{c}89,184 \\
(19,180)\end{array}$ & $\begin{array}{c}67,912 \\
(15,084)\end{array}$ & $\begin{array}{c}67,912 \\
(15,084)\end{array}$ & $\begin{array}{c}9,894 \\
(4,947)\end{array}$ & $\begin{array}{c}9,894 \\
(4,947)\end{array}$ & $\begin{array}{c}9,894 \\
(4,947)\end{array}$ & $\begin{array}{l}14,188 \\
(5,656)\end{array}$ & $\begin{array}{l}14,188 \\
(5,656)\end{array}$ \\
\hline
\end{tabular}


$* * * p<0.001, * * p<0.01, * p<0.05 ;$ robust standard errors in parentheses.

Data source: Panel "Labour Market and Social Security"; estimator: linear fixed effects; own calculations; results for survey wave dummies not reported; ${ }^{a)}$ single-member households excluded. 
Table A6: Test of the buffering hypothesis based on fixed effects regressions (full table)

\begin{tabular}{|c|c|c|c|c|c|c|}
\hline \multirow{2}{*}{$\begin{array}{l}\text { Dep. var.: mental health }(1-5) \\
\text { Indicator for social integration }\end{array}$} & \multicolumn{3}{|c|}{ Waves $1-10$} & \multicolumn{2}{|c|}{ Waves 3 and 5} & \multirow{2}{*}{$\begin{array}{c}\text { Waves } 3,5 \text { and } 9 \\
\begin{array}{c}\text { Job search social } \\
\text { support }\end{array}\end{array}$} \\
\hline & Weak ties & Strong ties & $\begin{array}{l}\text { Tensions and } \\
\text { conflicts }^{\text {a) }}\end{array}$ & $\begin{array}{l}\text { Employed } \\
\text { confidants }\end{array}$ & $\begin{array}{c}\text { General } \\
\text { social } \\
\text { support }\end{array}$ & \\
\hline & $\begin{array}{l}\text { Model } 1 \\
\text { Coef. }\end{array}$ & $\begin{array}{l}\text { Model } 2 \\
\text { Coef. }\end{array}$ & $\begin{array}{l}\text { Model } 3 \\
\text { Coef. }\end{array}$ & $\begin{array}{l}\text { Model } 4 \\
\text { Coef. }\end{array}$ & $\begin{array}{c}\text { Model } 5 \\
\text { Coef. }\end{array}$ & $\begin{array}{c}\text { Model } 6 \\
\text { Coef. }\end{array}$ \\
\hline Employment status (ref.: employed) & & & & & & \\
\hline Unemployed & $\begin{array}{c}-0.222 * * * \\
(0.018)\end{array}$ & $\begin{array}{c}-0.274 * * * \\
(0.030)\end{array}$ & $\begin{array}{c}-0.268 * * * \\
(0.038)\end{array}$ & $\begin{array}{l}-0.112 \\
(0.082)\end{array}$ & $\begin{array}{c}-0.384^{*} \\
(0.171)\end{array}$ & $\begin{array}{l}-0.235^{*} \\
(0.096)\end{array}$ \\
\hline Out of labor force & $\begin{array}{c}-0.067 * * * \\
(0.020)\end{array}$ & $\begin{array}{c}-0.123 * * * \\
(0.036)\end{array}$ & $\begin{array}{c}-0.099 * * \\
(0.038)\end{array}$ & $\begin{array}{c}0.067 \\
(0.100)\end{array}$ & $\begin{array}{l}-0.362 \\
(0.239)\end{array}$ & $\begin{array}{l}-0.221 \\
(0.117)\end{array}$ \\
\hline Indicator for social integration & $\begin{array}{c}0.004 \\
(0.009)\end{array}$ & $\begin{array}{c}0.032 * * * \\
(0.009)\end{array}$ & $\begin{array}{c}0.137 * * * \\
(0.008)\end{array}$ & $\begin{array}{l}0.060 * * \\
(0.023)\end{array}$ & $\begin{array}{l}-0.000 \\
(0.024)\end{array}$ & $\begin{array}{l}-0.014 \\
(0.018)\end{array}$ \\
\hline Indicator for social integration $*$ unemployed & $\begin{array}{l}-0.003 \\
(0.017)\end{array}$ & $\begin{array}{l}0.028^{*} \\
(0.014)\end{array}$ & $\begin{array}{c}0.023 \\
(0.013)\end{array}$ & $\begin{array}{l}-0.051 \\
(0.036)\end{array}$ & $\begin{array}{c}0.035 \\
(0.031)\end{array}$ & $\begin{array}{c}0.011 \\
(0.026)\end{array}$ \\
\hline Indicator for social integration $*$ out of labor force & $\begin{array}{c}0.010 \\
(0.015)\end{array}$ & $\begin{array}{l}0.032^{*} \\
(0.016)\end{array}$ & $\begin{array}{c}0.017 \\
(0.013)\end{array}$ & $\begin{array}{c}-0.085 * \\
(0.043)\end{array}$ & $\begin{array}{c}0.054 \\
(0.042)\end{array}$ & $\begin{array}{c}0.046 \\
(0.031)\end{array}$ \\
\hline General-education and vocational school (years) & $\begin{array}{c}0.019 \\
(0.010)\end{array}$ & $\begin{array}{c}0.019 \\
(0.010)\end{array}$ & $\begin{array}{c}0.007 \\
(0.012)\end{array}$ & $\begin{array}{l}-0.006 \\
(0.037)\end{array}$ & $\begin{array}{l}-0.001 \\
(0.038)\end{array}$ & $\begin{array}{c}0.005 \\
(0.030)\end{array}$ \\
\hline Work experience (months) & $\begin{array}{c}-0.001 * * * \\
(0.000)\end{array}$ & $\begin{array}{c}-0.001 * * * \\
(0.000)\end{array}$ & $\begin{array}{c}-0.001 * * * \\
(0.000)\end{array}$ & $\begin{array}{c}0.001 \\
(0.002)\end{array}$ & $\begin{array}{c}0.001 \\
(0.002)\end{array}$ & $\begin{array}{c}0.000 \\
(0.001)\end{array}$ \\
\hline Previous unemployment experience (yes/no) & $\begin{array}{c}0.049 \\
(0.042)\end{array}$ & $\begin{array}{c}0.049 \\
(0.042)\end{array}$ & $\begin{array}{c}0.053 \\
(0.045)\end{array}$ & $\begin{array}{l}-0.101 \\
(0.180)\end{array}$ & $\begin{array}{l}-0.085 \\
(0.180)\end{array}$ & $\begin{array}{l}-0.135 \\
(0.133)\end{array}$ \\
\hline Number of own children & $\begin{array}{c}-0.032 * * \\
(0.010)\end{array}$ & $\begin{array}{c}-0.033 * * * \\
(0.010)\end{array}$ & $\begin{array}{c}-0.032 * * \\
(0.011)\end{array}$ & $\begin{array}{c}0.007 \\
(0.038)\end{array}$ & $\begin{array}{c}0.007 \\
(0.038)\end{array}$ & $\begin{array}{l}-0.016 \\
(0.027)\end{array}$ \\
\hline Household size & $\begin{array}{c}0.001 \\
(0.009)\end{array}$ & $\begin{array}{c}0.003 \\
(0.009)\end{array}$ & $\begin{array}{c}0.001 \\
(0.011)\end{array}$ & $\begin{array}{c}0.002 \\
(0.034)\end{array}$ & $\begin{array}{l}-0.001 \\
(0.034)\end{array}$ & $\begin{array}{c}0.027 \\
(0.021)\end{array}$ \\
\hline Age groups (ref.: 55-64) & & & & & & \\
\hline$<25$ & $\begin{array}{c}0.100 \\
(0.056)\end{array}$ & $\begin{array}{c}0.101 \\
(0.056)\end{array}$ & $\begin{array}{c}0.021 \\
(0.063)\end{array}$ & $\begin{array}{l}-0.244 \\
(0.193)\end{array}$ & $\begin{array}{c}-0.242 \\
(0.194)\end{array}$ & $\begin{array}{l}-0.008 \\
(0.136)\end{array}$ \\
\hline $25-34$ & $\begin{array}{c}0.038 \\
(0.043)\end{array}$ & $\begin{array}{c}0.038 \\
(0.043)\end{array}$ & $\begin{array}{l}-0.026 \\
(0.048)\end{array}$ & $\begin{array}{l}-0.291 \\
(0.153)\end{array}$ & $\begin{array}{l}-0.294 \\
(0.153)\end{array}$ & $\begin{array}{l}-0.163 \\
(0.101)\end{array}$ \\
\hline $35-44$ & $\begin{array}{c}0.014 \\
(0.032)\end{array}$ & $\begin{array}{c}0.015 \\
(0.032)\end{array}$ & $\begin{array}{l}-0.019 \\
(0.036)\end{array}$ & $\begin{array}{l}-0.075 \\
(0.111)\end{array}$ & $\begin{array}{l}-0.076 \\
(0.111)\end{array}$ & $\begin{array}{l}-0.084 \\
(0.072)\end{array}$ \\
\hline $45-54$ & $\begin{array}{l}-0.004 \\
(0.021)\end{array}$ & $\begin{array}{l}-0.002 \\
(0.021)\end{array}$ & $\begin{array}{l}-0.015 \\
(0.024)\end{array}$ & $\begin{array}{l}-0.002 \\
(0.076)\end{array}$ & $\begin{array}{l}-0.000 \\
(0.076)\end{array}$ & $\begin{array}{l}-0.062 \\
(0.045)\end{array}$ \\
\hline Within $\mathrm{R}^{2}$ & 0.005 & 0.006 & 0.018 & 0.006 & 0.006 & 0.005 \\
\hline Observations & 89,184 & 89,184 & 67,912 & 9,894 & 9,894 & 14,188 \\
\hline
\end{tabular}


Table A7: Test of the causal pathway hypothesis based on fixed effects regressions: self-rated health as alternative outcome

\begin{tabular}{|c|c|c|c|c|c|c|}
\hline Indicator for social integration & $\beta_{1}$ & $\gamma_{1}$ & $\delta_{1}$ & $\begin{array}{c}\text { Indirect effect } \\
\gamma_{1} \cdot \delta_{1}\end{array}$ & $\begin{array}{c}\text { Observations } \\
\text { (persons) }\end{array}$ & Waves \\
\hline Weak ties & $\begin{array}{c}-0.080 * * * \\
(0.013)\end{array}$ & $\begin{array}{l}-0.002 \\
(0.006)\end{array}$ & $\begin{array}{l}-0.008 \\
(0.008)\end{array}$ & $\begin{array}{c}0.000 \\
(0.000)\end{array}$ & $\begin{array}{c}89,184 \\
(19,180)\end{array}$ & 1 to 10 \\
\hline Strong ties & $\begin{array}{c}-0.080 * * * \\
(0.013)\end{array}$ & $\begin{array}{c}0.036^{* * * *} \\
(0.006)\end{array}$ & $\begin{array}{l}-0.018 \\
(0.009)\end{array}$ & $\begin{array}{l}-0.001 \\
(0.000)\end{array}$ & $\begin{array}{c}89,184 \\
(19,180)\end{array}$ & 1 to 10 \\
\hline Tensions and conflicts ${ }^{\text {a) }}$ & $\begin{array}{c}-0.069 * * * \\
(0.015)\end{array}$ & $\begin{array}{c}0.054 * * * \\
(0.005)\end{array}$ & $\begin{array}{c}0.013 \\
(0.015)\end{array}$ & $\begin{array}{c}0.001 \\
(0.001)\end{array}$ & $\begin{array}{c}67,912 \\
(15,084)\end{array}$ & 1 to 10 \\
\hline Employed confidants & $\begin{array}{l}-0.081 \\
(0.047)\end{array}$ & $\begin{array}{c}0.006 \\
(0.015)\end{array}$ & $\begin{array}{c}-0.139 * * \\
(0.047)\end{array}$ & $\begin{array}{l}-0.001 \\
(0.002)\end{array}$ & $\begin{array}{c}9,894 \\
(4,947)\end{array}$ & 3 and 5 \\
\hline General social support & $\begin{array}{l}-0.081 \\
(0.047)\end{array}$ & $\begin{array}{c}0.040 * * \\
(0.014)\end{array}$ & $\begin{array}{c}-0.146 * * \\
(0.050)\end{array}$ & $\begin{array}{l}-0.006^{*} \\
(0.003)\end{array}$ & $\begin{array}{c}9,894 \\
(4,947)\end{array}$ & 3 and 5 \\
\hline Job search social support & $\begin{array}{c}-0.098 * * \\
(0.033)\end{array}$ & $\begin{array}{c}0.002 \\
(0.010)\end{array}$ & $\begin{array}{l}-0.001 \\
(0.034)\end{array}$ & $\begin{array}{l}-0.000 \\
(0.000)\end{array}$ & $\begin{array}{l}14,188 \\
(5,656)\end{array}$ & 3,5 and 9 \\
\hline
\end{tabular}

*** $p<0.001, * * p<0.01, * p<0.05 ;$ robust standard errors in parentheses.

Data source: Panel "Labour Market and Social Security"; estimator: linear fixed effects; own calculations.

$\beta_{1}$ : Coefficient of unemployment on self-rated health (Equation (3) applied to self-rated health); $\gamma_{1}$ : Coefficient of the respective social integration variable on self-rated health (Equation (4) applied to self-rated health); $\delta_{1}$ : Coefficient of unemployment on the respective variable of social integration from Equation (5); Indirect effect: $\gamma_{1} \cdot \delta_{1}$; part of the unemployment-health effect mediated by the respective social integration variable; standard errors of the indirect effects based on a Sobel test; the respective values from the Aroian test slightly differ but lead to identical conclusions regarding the significance level; controls: generaleducation and vocational school (years), work experience (months), previous unemployment experience (yes/no), number of own children, household size, age groups, survey wave dummies; ${ }^{a)}$ single-member

households excluded. 
Table A8: Test of the buffering hypothesis based on fixed effects regressions: self-rated health as alternative outcome

\begin{tabular}{|c|c|c|c|c|c|c|}
\hline Dep. var.: self-rated health (1-5) & \multicolumn{3}{|c|}{ Waves $1-10$} & \multicolumn{2}{|c|}{ Waves 3 and 5} & \multirow{2}{*}{$\begin{array}{c}\text { Waves } 3,5 \text { and } 9 \\
\begin{array}{c}\text { Job search social } \\
\text { support }\end{array}\end{array}$} \\
\hline \multirow[t]{2}{*}{ Indicator for social integration } & Weak ties & Strong ties & $\begin{array}{l}\text { Tensions and } \\
\text { conflicts }^{\mathrm{d})}\end{array}$ & $\begin{array}{l}\text { Employed } \\
\text { confidants }\end{array}$ & $\begin{array}{c}\text { General } \\
\text { social } \\
\text { support } \\
\end{array}$ & \\
\hline & Model 1 & Model 2 & Model 3 & Model 4 & Model 5 & Model 6 \\
\hline Employment status (ref.: employed $)^{a) b}$ & Coef. & Coef. & Coef. & Coef. & Coef. & Coef. \\
\hline Unemployed $\left(\beta_{3}\right)$ & $\begin{array}{c}-0.079 * * * \\
(0.014)\end{array}$ & $\begin{array}{c}-0.109 * * * \\
(0.024)\end{array}$ & $\begin{array}{c}-0.085^{* *} \\
(0.031)\end{array}$ & $\begin{array}{l}-0.072 \\
(0.067)\end{array}$ & $\begin{array}{l}-0.183 \\
(0.138)\end{array}$ & $\begin{array}{c}-0.217 * * \\
(0.076)\end{array}$ \\
\hline Indicator for social integration $\left(\gamma_{2}\right)$ & $\begin{array}{l}-0.004 \\
(0.007)\end{array}$ & $\begin{array}{c}0.031 * * * \\
(0.008)\end{array}$ & $\begin{array}{c}0.049 * * * \\
(0.007)\end{array}$ & $\begin{array}{c}0.013 \\
(0.019)\end{array}$ & $\begin{array}{c}0.022 \\
(0.020)\end{array}$ & $\begin{array}{l}-0.017 \\
(0.014)\end{array}$ \\
\hline Indicator for social integration * unemployed $\left(\delta_{2}\right)$ & $\begin{array}{l}-0.007 \\
(0.014)\end{array}$ & $\begin{array}{c}0.016 \\
(0.011)\end{array}$ & $\begin{array}{c}0.006 \\
(0.011)\end{array}$ & $\begin{array}{l}-0.004 \\
(0.032)\end{array}$ & $\begin{array}{c}0.020 \\
(0.025)\end{array}$ & $\begin{array}{c}0.035 \\
(0.020)\end{array}$ \\
\hline Controls included?c) & yes & yes & yes & yes & yes & yes \\
\hline Within $\mathrm{R}^{2}$ & 0.011 & 0.012 & 0.014 & 0.004 & 0.006 & 0.012 \\
\hline $\begin{array}{l}\text { Observations } \\
\text { (persons) }\end{array}$ & $\begin{array}{c}89,184 \\
(19,180) \\
\end{array}$ & $\begin{array}{c}89,184 \\
(19,180) \\
\end{array}$ & $\begin{array}{c}67,912 \\
(15,084)\end{array}$ & $\begin{array}{c}9,894 \\
(4,947)\end{array}$ & $\begin{array}{c}9,894 \\
(4,947) \\
\end{array}$ & $\begin{array}{l}14,188 \\
(5,656)\end{array}$ \\
\hline
\end{tabular}


Table A9: Test of the causal pathway hypothesis based on fixed effects regressions: unemployment duration (years)

\begin{tabular}{|c|c|c|c|c|c|c|}
\hline Indicator for social integration & $\beta_{1}$ & $\gamma_{1}$ & $\delta_{1}$ & $\begin{array}{c}\text { Indirect effect } \\
\gamma_{1} \cdot \delta_{1}\end{array}$ & $\begin{array}{c}\text { Observations } \\
\text { (persons) }\end{array}$ & Waves \\
\hline Weak ties & $\begin{array}{c}-0.016 * * * \\
(0.003)\end{array}$ & $\begin{array}{c}0.004 \\
(0.008)\end{array}$ & $\begin{array}{c}-0.003 * \\
(0.001)\end{array}$ & $\begin{array}{l}-0.000 \\
(0.000)\end{array}$ & $\begin{array}{c}88,048 \\
(19,100)\end{array}$ & 1 to 10 \\
\hline Strong ties & $\begin{array}{c}-0.016 * * * \\
(0.003)\end{array}$ & $\begin{array}{c}0.048^{* * * *} \\
(0.007)\end{array}$ & $\begin{array}{l}-0.002 \\
(0.002)\end{array}$ & $\begin{array}{l}-0.000 \\
(0.000)\end{array}$ & $\begin{array}{c}88,048 \\
(19,100)\end{array}$ & 1 to 10 \\
\hline Tensions and conflicts ${ }^{\mathrm{a}}$ & $\begin{array}{c}-0.015^{* * * *} \\
(0.004)\end{array}$ & $\begin{array}{c}0.146 * * * \\
(0.006)\end{array}$ & $\begin{array}{c}0.001 \\
(0.003)\end{array}$ & $\begin{array}{c}0.000 \\
(0.000)\end{array}$ & $\begin{array}{c}67,142 \\
(15,038)\end{array}$ & 1 to 10 \\
\hline Employed confidants & $\begin{array}{l}-0.022^{*} \\
(0.009)\end{array}$ & $\begin{array}{c}0.030 \\
(0.017)\end{array}$ & $\begin{array}{l}-0.004 \\
(0.008)\end{array}$ & $\begin{array}{l}-0.000 \\
(0.000)\end{array}$ & $\begin{array}{c}9,770 \\
(4,907)\end{array}$ & 3 and 5 \\
\hline General social support & $\begin{array}{l}-0.022^{*} \\
(0.009)\end{array}$ & $\begin{array}{c}0.026 \\
(0.017)\end{array}$ & $\begin{array}{l}-0.014 \\
(0.013)\end{array}$ & $\begin{array}{l}-0.000 \\
(0.000)\end{array}$ & $\begin{array}{c}9,770 \\
(4,907)\end{array}$ & 3 and 5 \\
\hline Job search social support & $\begin{array}{l}-0.014 * \\
(0.006)\end{array}$ & $\begin{array}{l}-0.002 \\
(0.013)\end{array}$ & $\begin{array}{c}0.001 \\
(0.007)\end{array}$ & $\begin{array}{l}-0.000 \\
(0.000)\end{array}$ & $\begin{array}{l}14,025 \\
(5,618)\end{array}$ & 3,5 and 9 \\
\hline
\end{tabular}

*** $p<0.001, * * p<0.01, * p<0.05 ;$ robust standard errors in parentheses.

Data source: Panel "Labour Market and Social Security"; estimator: linear fixed effects; own calculations.

$\beta_{1}$ : Coefficient of unemployment duration on mental health from Equation (3); $\gamma_{1}$ : Coefficient of the respective social integration variable on mental health from Equation (4); $\delta_{1}$ : Coefficient of unemployment

duration on the respective variable of social integration from Equation (5); Indirect effect: $\gamma_{1} \cdot \delta_{1}$; part of the unemployment-health effect mediated by the respective social integration variable; standard errors of the indirect effects based on a Sobel test; the respective values from the Aroian test slightly differ but lead to identical conclusions regarding the significance level; controls: general-education and vocational school

(years), work experience (months), previous unemployment experience (yes/no), number of own children household size, age groups, survey wave dummies: a) single-member households excluded. 
Table A10: Test of the buffering hypothesis based on fixed effects regressions: unemployment duration (years)

\begin{tabular}{|c|c|c|c|c|c|c|}
\hline Dep. var.: mental health (1-5) & \multicolumn{3}{|c|}{ Waves $1-10$} & \multicolumn{2}{|c|}{ Waves 3 and 5} & \multirow{2}{*}{$\begin{array}{c}\text { Waves } 3,5 \text { and } 9 \\
\begin{array}{c}\text { Job search social } \\
\text { support }\end{array}\end{array}$} \\
\hline \multirow[t]{2}{*}{ Indicator for social integration } & Weak ties & Strong ties & $\begin{array}{l}\text { Tensions and } \\
\text { conflicts }^{b}\end{array}$ & $\begin{array}{l}\text { Employed } \\
\text { confidants }\end{array}$ & $\begin{array}{c}\text { General } \\
\text { social } \\
\text { support }\end{array}$ & \\
\hline & $\begin{array}{l}\text { Model } 1 \\
\text { Coef. }\end{array}$ & $\begin{array}{l}\text { Model } 2 \\
\text { Coef. }\end{array}$ & $\begin{array}{l}\text { Model } 3 \\
\text { Coef. }\end{array}$ & $\begin{array}{c}\text { Model } 4 \\
\text { Coef. }\end{array}$ & $\begin{array}{l}\text { Model } 5 \\
\text { Coef. }\end{array}$ & $\begin{array}{l}\text { Model } 6 \\
\text { Coef. }\end{array}$ \\
\hline Unemployment duration $\left(\beta_{3}\right)$ & $\begin{array}{c}-0.016 * * * \\
(0.003)\end{array}$ & $\begin{array}{c}-0.012^{*} \\
(0.005)\end{array}$ & $\begin{array}{c}-0.022 * * * \\
(0.006)\end{array}$ & $\begin{array}{l}-0.016 \\
(0.012)\end{array}$ & $\begin{array}{l}-0.025 \\
(0.015)\end{array}$ & $\begin{array}{l}-0.002 \\
(0.010)\end{array}$ \\
\hline Indicator for social integration $\left(\gamma_{2}\right)$ & $\begin{array}{c}0.005 \\
(0.008)\end{array}$ & $\begin{array}{c}0.052 * * * \\
(0.008)\end{array}$ & $\begin{array}{c}0.143 * * * \\
(0.007)\end{array}$ & $\begin{array}{c}0.036 \\
(0.019)\end{array}$ & $\begin{array}{c}0.024 \\
(0.019)\end{array}$ & $\begin{array}{c}0.007 \\
(0.014)\end{array}$ \\
\hline Indicator for social integration $*$ unemployment duration $\left(\delta_{2}\right)$ & $\begin{array}{l}-0.002 \\
(0.003)\end{array}$ & $\begin{array}{l}-0.003 \\
(0.002)\end{array}$ & $\begin{array}{c}0.003 \\
(0.002)\end{array}$ & $\begin{array}{l}-0.005 \\
(0.006)\end{array}$ & $\begin{array}{c}0.001 \\
(0.003)\end{array}$ & $\begin{array}{l}-0.004 \\
(0.003)\end{array}$ \\
\hline Controls included?a) & yes & yes & yes & yes & yes & yes \\
\hline Within $\mathrm{R}^{2}$ & 0.002 & 0.003 & 0.015 & 0.003 & 0.003 & 0.002 \\
\hline $\begin{array}{l}\text { Observations } \\
\text { (persons) }\end{array}$ & $\begin{array}{c}88,048 \\
(19,100)\end{array}$ & $\begin{array}{c}88,048 \\
(19,100)\end{array}$ & $\begin{array}{c}67,142 \\
(15,038)\end{array}$ & $\begin{array}{c}9,770 \\
(4,907)\end{array}$ & $\begin{array}{c}9,770 \\
(4,907)\end{array}$ & $\begin{array}{l}14,025 \\
(5,618)\end{array}$ \\
\hline
\end{tabular}

(persons)

$(4,907)$

$(4,907)$

$(5,618)$

Data source: Panel "Labour Market and Social Security"; estimator: linear fixed effects; own calculations; a) controls: general-education and vocational school (years), work experience (months), previous unemployment experience (yes/no), number of own children, household size, age groups, survey wave dummies; ${ }^{b}$ single-member households excluded. 
Table A11: Test of the causal pathway hypothesis based on fixed effects regressions: social integration dummies

\begin{tabular}{|c|c|c|c|c|c|c|}
\hline Indicator for social integration & $\beta_{1}$ & $\gamma_{1}$ & $\delta_{1}$ & $\begin{array}{c}\text { Indirect effect } \\
\gamma_{1} \cdot \delta_{1}\end{array}$ & $\begin{array}{l}\text { Observations } \\
\text { (persons) }\end{array}$ & Waves \\
\hline Weak ties $($ yes $=1 /$ no $=0)$ & $\begin{array}{c}-0.223 * * * \\
(0.016)\end{array}$ & $\begin{array}{c}0.018 \\
(0.011)\end{array}$ & $\begin{array}{l}-0.010 \\
(0.006)\end{array}$ & $\begin{array}{l}-0.000 \\
(0.000)\end{array}$ & $\begin{array}{c}89,184 \\
(19,180)\end{array}$ & 1 to 10 \\
\hline General social support $($ yes $=1 /$ no $=0$ ) & $\begin{array}{c}-0.202 * * * \\
(0.056)\end{array}$ & $\begin{array}{l}-0.075 \\
(0.152)\end{array}$ & $\begin{array}{c}0.001 \\
(0.005)\end{array}$ & $\begin{array}{l}-0.000 \\
(0.000)\end{array}$ & $\begin{array}{c}9,894 \\
(4,947)\end{array}$ & 3 and 5 \\
\hline Job search social support $($ yes $=1 /$ no $=0$ ) & $\begin{array}{c}-0.195^{* * *} \\
(0.041)\end{array}$ & $\begin{array}{l}-0.052 \\
(0.062)\end{array}$ & $\begin{array}{c}0.006 \\
(0.007)\end{array}$ & $\begin{array}{l}-0.000 \\
(0.001)\end{array}$ & $\begin{array}{l}14,188 \\
(5,656)\end{array}$ & 3,5 and 9 \\
\hline
\end{tabular}

$* * * p<0.001, * * p<0.01, * p<0.05 ;$ robust standard errors in parentheses.

Data source: Panel "Labour Market and Social Security"; estimator: linear fixed effects; own calculations.

$\beta_{1}$ : Coefficient of unemployment on mental health from Equation (3); $\gamma_{1}$ : Coefficient of the respective social integration variable on mental health from Equation (4); $\delta_{1}$ : Coefficient of unemployment on the

respective variable of social integration from Equation (5); Indirect effect: $\gamma_{1} \cdot \delta_{1}$; part of the unemployment-health effect mediated by the respective social integration variable; standard errors of the indirect effects

based on a Sobel test; the respective values from the Aroian test slightly differ but lead to identical conclusions regarding the significance level; controls: general-education and vocational school (years), work

experience (months), previous unemployment experience (yes/no), number of own children, household size, age groups, survey wave dummies. 
Table A12: Test of the buffering hypothesis based on fixed effects regressions: social integration dummies

\begin{tabular}{|c|c|c|c|}
\hline Dep. var.: mental health (1-5) & Waves $1-10$ & Waves 3 and 5 & Waves 3,5 and 9 \\
\hline Indicator for social integration & $\begin{array}{l}\text { Weak ties (yes } \\
\quad=1 / \text { no }=0)\end{array}$ & $\begin{array}{c}\text { General social } \\
\text { support }(\text { yes }=1 / \text { no } \\
=0)\end{array}$ & $\begin{array}{c}\text { Job search social } \\
\text { support (yes }=1 / \text { no } \\
=0)\end{array}$ \\
\hline & $\begin{array}{l}\text { Model } 1 \\
\text { Coef. }\end{array}$ & $\begin{array}{l}\text { Model } 5 \\
\text { Coef. }\end{array}$ & $\begin{array}{l}\text { Model } 6 \\
\text { Coef. }\end{array}$ \\
\hline Employment status (ref.: employed $)^{a) b)}$ & & & \\
\hline Unemployed $\left(\beta_{3}\right)$ & $\begin{array}{c}-0.217 * * * \\
(0.018)\end{array}$ & $\begin{array}{c}0.220 \\
(0.284)\end{array}$ & $\begin{array}{c}-0.092 \\
(0.128)\end{array}$ \\
\hline Indicator for social integration $\left(\gamma_{2}\right)$ & $\begin{array}{c}0.018 \\
(0.014)\end{array}$ & $\begin{array}{c}0.204 \\
(0.272)\end{array}$ & $\begin{array}{l}-0.046 \\
(0.102)\end{array}$ \\
\hline Indicator for social integration $*$ unemployed $\left(\delta_{2}\right)$ & -0.021 & -0.429 & -0.110 \\
\hline & $(0.024)$ & $(0.285)$ & $(0.128)$ \\
\hline Controls included? ${ }^{\mathrm{c}}$ & yes & yes & yes \\
\hline Within $\mathrm{R}^{2}$ & 0.006 & 0.005 & 0.005 \\
\hline $\begin{array}{l}\text { Observations } \\
\text { (persons) }\end{array}$ & $\begin{array}{c}89,184 \\
(19,180)\end{array}$ & $\begin{array}{c}9,894 \\
(4,947)\end{array}$ & $\begin{array}{l}14,188 \\
(5,656)\end{array}$ \\
\hline
\end{tabular}

(persons)

$(4,947)$

$(5,656)$

Data source: Panel "Labour Market and Social Security"; estimator: linear fixed effects; own calculations; ${ }^{a)}$ results for "out of labor force" (OLF) category not reported; ${ }^{b}$ interaction effect of unemployment and OLF not reported; ${ }^{c}$ controls: general-education and vocational school (years), work experience (months), previous unemployment experience (yes/no), number of own children, household size, age groups, survey wave dummies. 
Table A13: Mental health trajectory prior to unemployment based on fixed effects regressions

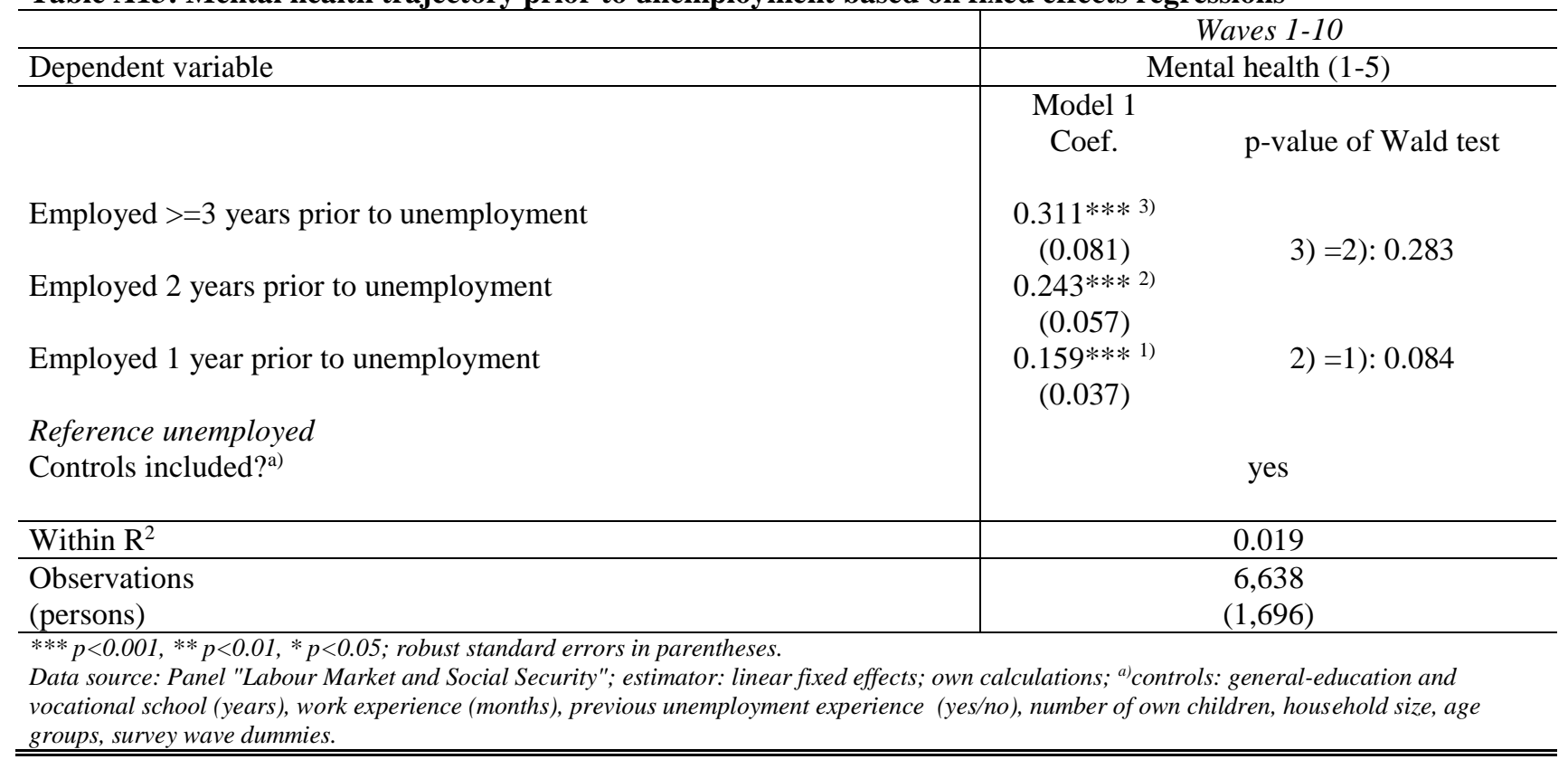


Table A14: Trajectory of social integration prior to unemployment based on fixed effects regressions

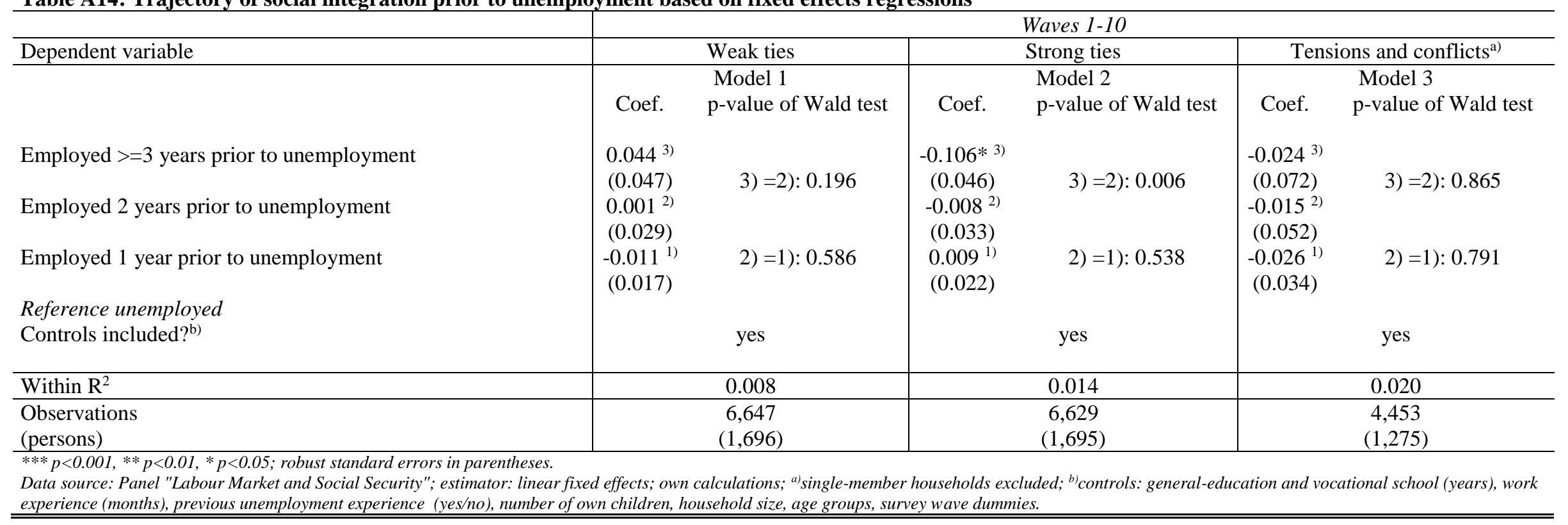




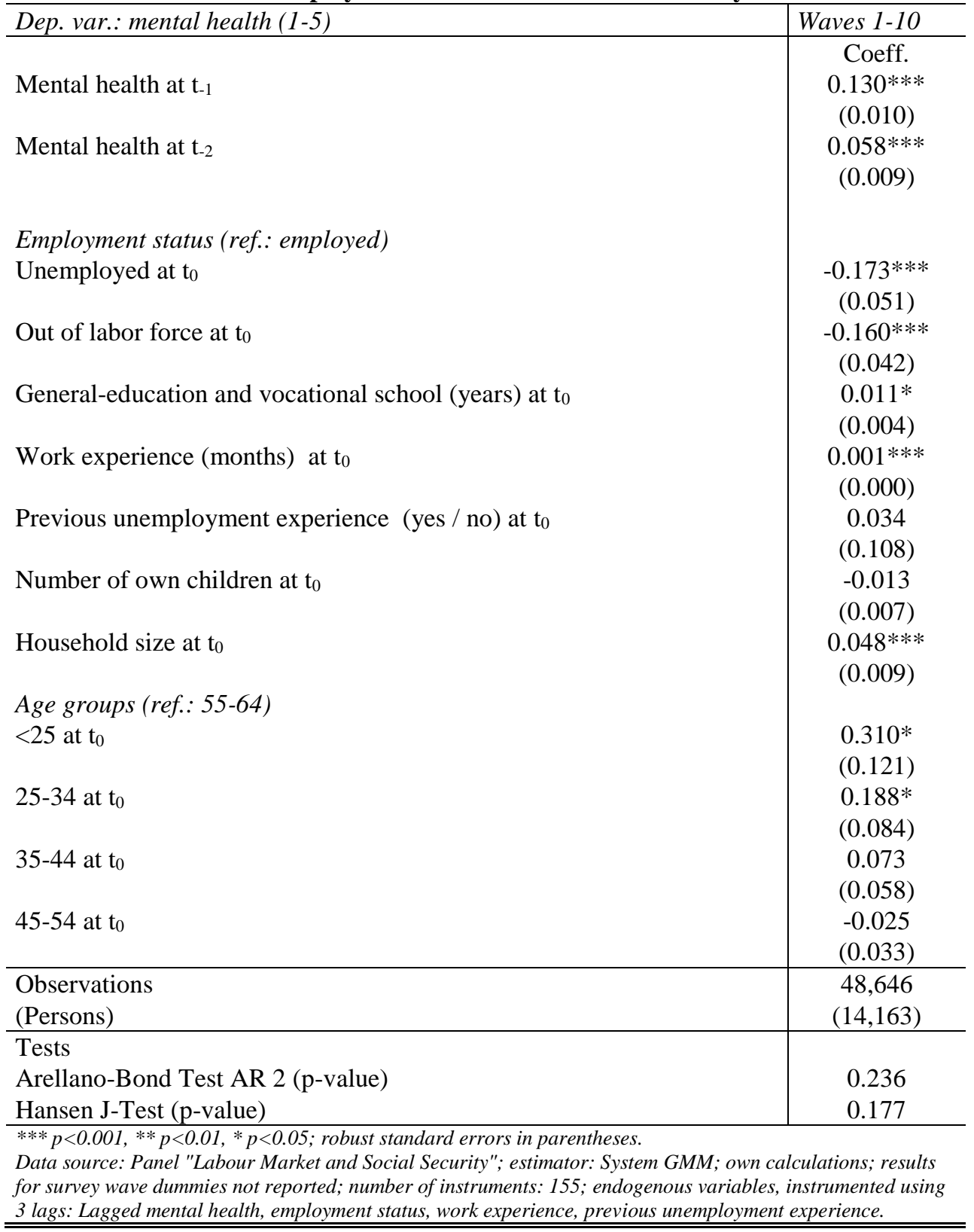


Table A16: Test of the causal pathway hypothesis based on pooled OLS regressions

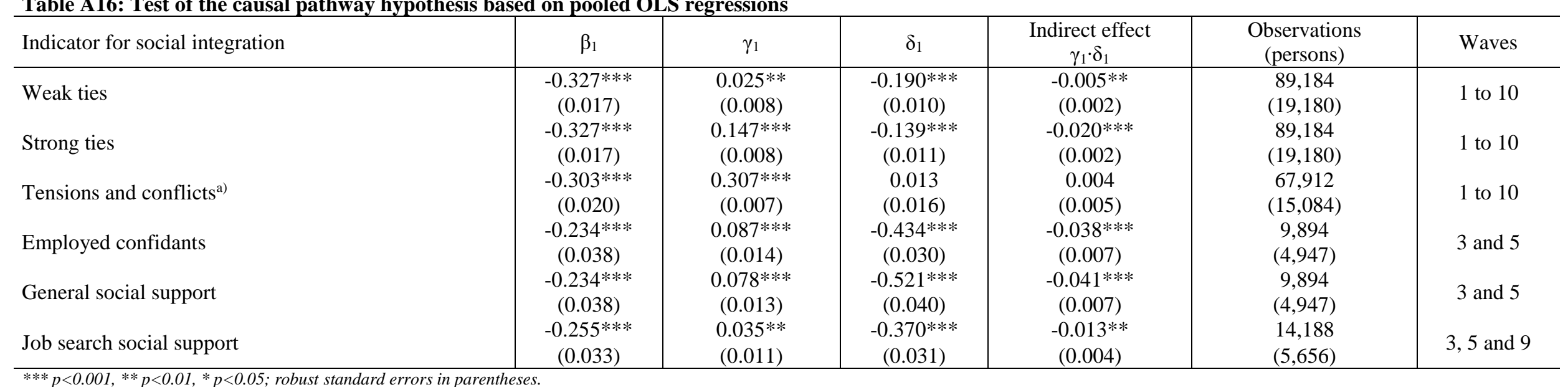

$* * * p<0.001, * * p<0.01, * p<0.05 ;$ robust standard errors in parentheses.

Data source: Panel "Labour Market and Social Security"; estimator: Pooled OLS; own calculations.

$\beta_{1}$ : Coefficient of unemployment on mental health from Equation (3); $\gamma_{1}$ : Coefficient of the respective social integration variable on mental health from Equation (4); $\delta_{1}$ : Coefficient of unemployment on the respective variable of social integration from Equation (5); Indirect effect: $\gamma_{1} \cdot \delta_{1}$; part of the unemployment-health effect mediated by the respective social integration variable; standard errors of the indirect effects based on a Sobel test; the respective values from the Aroian test slightly differ but lead to identical conclusions regarding the significance level; controls: general-education and vocational school (years), work experience (months),

previous unemployment experience (yes/no), number of own children, household size, age groups, survey wave dummies; ${ }^{a}$ single-member households excluded. 
Table A17: Test of the buffering hypothesis based on pooled OLS regressions

\begin{tabular}{|c|c|c|c|c|c|c|}
\hline Dep. var.: mental health (1-5) & \multicolumn{3}{|c|}{ Waves $1-10$} & \multicolumn{2}{|c|}{ Waves 3 and 5} & Waves 3, 5 and 9 \\
\hline Indicator for social integration & Weak ties & Strong ties & $\begin{array}{c}\text { Tensions and } \\
\text { conflicts }^{\mathrm{d})}\end{array}$ & $\begin{array}{l}\text { Employed } \\
\text { confidants }\end{array}$ & $\begin{array}{c}\text { General social } \\
\text { support }\end{array}$ & $\begin{array}{c}\text { Job search social } \\
\text { support }\end{array}$ \\
\hline & $\begin{array}{l}\text { Model } 1 \\
\text { Coef. }\end{array}$ & $\begin{array}{l}\text { Model } 2 \\
\text { Coef. }\end{array}$ & $\begin{array}{l}\text { Model } 3 \\
\text { Coef. }\end{array}$ & $\begin{array}{c}\text { Model } 4 \\
\text { Coef. }\end{array}$ & $\begin{array}{l}\text { Model } 5 \\
\text { Coef. }\end{array}$ & $\begin{array}{l}\text { Model } 6 \\
\text { Coef. }\end{array}$ \\
\hline Employment status (ref.: employed) $)^{a) b}$ & & & & & & \\
\hline Unemployed $\left(\beta_{3}\right)$ & $\begin{array}{c}-0.327 * * * \\
(0.019)\end{array}$ & $\begin{array}{c}-0.447 * * * \\
(0.036)\end{array}$ & $\begin{array}{c}-0.423 * * * \\
(0.043)\end{array}$ & $\begin{array}{l}-0.088 \\
(0.062)\end{array}$ & $\begin{array}{l}-0.007 \\
(0.144)\end{array}$ & $\begin{array}{l}-0.121 \\
(0.085)\end{array}$ \\
\hline Indicator for social integration $\left(\gamma_{2}\right)$ & $\begin{array}{c}0.009 \\
(0.009)\end{array}$ & $\begin{array}{c}0.098 * * * \\
(0.011)\end{array}$ & $\begin{array}{c}0.290 * * * \\
(0.009)\end{array}$ & $\begin{array}{c}0.108 * * * \\
(0.018)\end{array}$ & $\begin{array}{c}0.088 * * * \\
(0.019)\end{array}$ & $\begin{array}{l}0.032 * \\
(0.016)\end{array}$ \\
\hline Indicator for social integration * unemployed $\left(\delta_{2}\right)$ & $\begin{array}{l}-0.003 \\
(0.021)\end{array}$ & $\begin{array}{c}0.077 * * * \\
(0.017)\end{array}$ & $\begin{array}{c}0.047 * * \\
(0.015)\end{array}$ & $\begin{array}{l}-0.072 * \\
(0.031)\end{array}$ & $\begin{array}{l}-0.038 \\
(0.026)\end{array}$ & $\begin{array}{l}-0.041 \\
(0.024)\end{array}$ \\
\hline Controls included? $?^{\mathrm{c}}$ & yes & yes & yes & yes & yes & yes \\
\hline $\mathrm{R}^{2}$ & 0.036 & 0.044 & 0.090 & 0.038 & 0.039 & 0.035 \\
\hline $\begin{array}{l}\text { Observations } \\
\text { (persons) }\end{array}$ & $\begin{array}{c}89,184 \\
(19,180) \\
\end{array}$ & $\begin{array}{c}89,184 \\
(19,180) \\
\end{array}$ & $\begin{array}{c}67,912 \\
(15,084) \\
\end{array}$ & $\begin{array}{c}9,894 \\
(4,947) \\
\end{array}$ & $\begin{array}{c}9,894 \\
(4,947) \\
\end{array}$ & $\begin{array}{l}14,188 \\
(5,656) \\
\end{array}$ \\
\hline
\end{tabular}


Table A18: Test of the causal pathway hypothesis based on fixed effects regressions: strong ties not logarithmized

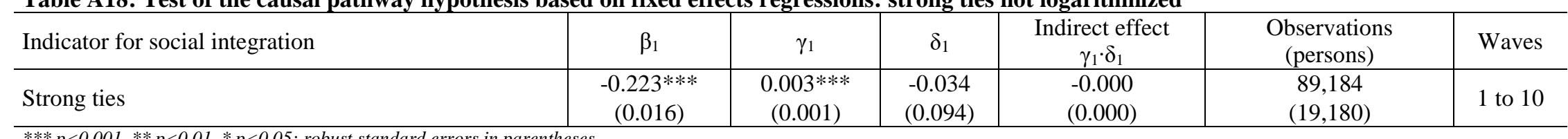

*** $p<0.001, * * p<0.01, * p<0.05 ;$ robust standard errors in parentheses.

Data source: Panel "Labour Market and Social Security"; estimator: linear fixed effects; own calculations.

$\beta_{1}$ : Coefficient of unemployment on mental health from Equation (3); $\gamma_{1}$ : Coefficient of the respective social integration variable on mental health from Equation (4); $\delta_{1}$ : Coefficient of unemployment on the respective variable of social integration from Equation (5); Indirect effect: $\gamma_{1} \cdot \delta_{1}$; part of the unemployment-health effect mediated by the respective social integration variable; standard errors of the indirect effects based on a Sobel test; the respective values from the Aroian test slightly differ but lead to identical conclusions regarding the significance level; controls: general-education and vocational school (years), work experience (months), previous unemployment experience (yes/no), number of own children, household size, age groups, survey wave dummies.

Table A19: Test of the buffering hypothesis based on fixed effects regressions: strong ties not logarithmized Dep. var.: mental health (1-5)

Indicator for social integration

Strong tie

Model 1

Employment status (ref.: employed $)^{a) b}$

Unemployed $\left(\beta_{3}\right)$

Indicator for social integration $\left(\gamma_{2}\right)$

Indicator for social integration * unemployed $\left(\delta_{2}\right)$

Controls included?

$(0.019)$

$0.002 *$

$(0.001)$

0.002

$(0.001)$

yes

\begin{tabular}{l|c}
\hline Within $\mathrm{R}^{2}$ & 0.006 \\
\hline $\begin{array}{l}\text { Observations } \\
\text { (persons) }\end{array}$ & 89,184 \\
\hline$* * * p<0.001, * * p<0.01, * p<0.05 ;$ robust standard errors in parentheses. & $(19,180)$ \\
\hline
\end{tabular}

(persons)

Data source: Panel "Labour Market and Social Security"; estimator: linear fixed effects; own calculations; ${ }^{\text {a) }}$ results for "out of labor force" (OLF

category not reported; ${ }^{b}$ interaction effect of unemployment and OLF not reported; ${ }^{c}$ controls: general-education and vocational school (years), work

experience (months), previous unemployment experience (yes/no), number of own children, household size, age groups, survey wave dummies. 
Table A20: Test of the causal pathway hypothesis based on fixed effects regressions: household income as additional control

\begin{tabular}{|c|c|c|c|c|c|c|}
\hline Indicator for social integration & $\beta_{1}$ & $\gamma_{1}$ & $\delta_{1}$ & $\begin{array}{c}\text { Indirect effect } \\
\gamma_{1} \cdot \delta_{1} \\
\end{array}$ & $\begin{array}{c}\text { Observations } \\
\text { (persons) }\end{array}$ & Waves \\
\hline Weak ties & $\begin{array}{c}-0.220 * * * \\
(0.016)\end{array}$ & $\begin{array}{c}0.006 \\
(0.008)\end{array}$ & $\begin{array}{l}-0.007 \\
(0.008)\end{array}$ & $\begin{array}{l}-0.000 \\
(0.000)\end{array}$ & $\begin{array}{c}88,268 \\
(19,159)\end{array}$ & 1 to 10 \\
\hline Strong ties & $\begin{array}{c}-0.220 * * * \\
(0.016)\end{array}$ & $\begin{array}{c}0.048 * * * \\
(0.007)\end{array}$ & $\begin{array}{l}-0.017 \\
(0.009)\end{array}$ & $\begin{array}{l}-0.001 \\
(0.000)\end{array}$ & $\begin{array}{c}88,268 \\
(19,159)\end{array}$ & 1 to 10 \\
\hline Tensions and conflicts ${ }^{\text {a) }}$ & $\begin{array}{c}-0.206 * * * \\
(0.019)\end{array}$ & $\begin{array}{c}0.146^{* * *} * \\
(0.006)\end{array}$ & $\begin{array}{c}0.013 \\
(0.015)\end{array}$ & $\begin{array}{c}0.002 \\
(0.002)\end{array}$ & $\begin{array}{c}67,088 \\
(15,061)\end{array}$ & 1 to 10 \\
\hline Employed confidants & $\begin{array}{c}-0.201 * * * \\
(0.056)\end{array}$ & $\begin{array}{c}0.027 \\
(0.017)\end{array}$ & $\begin{array}{c}-0.139 * * \\
(0.047)\end{array}$ & $\begin{array}{l}-0.004 \\
(0.003)\end{array}$ & $\begin{array}{c}9,822 \\
(4,942)\end{array}$ & 3 and 5 \\
\hline General social support & $\begin{array}{c}-0.201 * * * \\
(0.056)\end{array}$ & $\begin{array}{c}0.026 \\
(0.017)\end{array}$ & $\begin{array}{c}-0.142 * * \\
(0.050)\end{array}$ & $\begin{array}{l}-0.004 \\
(0.003)\end{array}$ & $\begin{array}{c}9,822 \\
(4,942)\end{array}$ & 3 and 5 \\
\hline Job search social support & $\begin{array}{c}-0.195 * * * \\
(0.041)\end{array}$ & $\begin{array}{l}-0.000 \\
(0.013) \\
\end{array}$ & $\begin{array}{c}0.005 \\
(0.034) \\
\end{array}$ & $\begin{array}{l}-0.000 \\
(0.000)\end{array}$ & $\begin{array}{l}14,094 \\
(5,652)\end{array}$ & 3,5 and 9 \\
\hline
\end{tabular}

*** $p<0.001, * * p<0.01, * p<0.05 ;$ robust standard errors in parentheses.

Data source: Panel "Labour Market and Social Security"; estimator: linear fixed effects; own calculations.

$\beta_{1}$ : Coefficient of unemployment on mental health from Equation (3); $\gamma_{1}$ : Coefficient of the respective social integration variable on mental health from Equation (4); $\delta_{1}$ : Coefficient of unemployment on the respective variable of social integration from Equation (5); Indirect effect: $\gamma_{1} \cdot \delta_{1} ;$; part of the unemployment-health effect mediated by the respective social integration variable; standard errors of the indirect effects based on a Sobel test; the respective values from the Aroian test slightly differ but lead to identical conclusions regarding the significance level; controls: household income, general-education and vocational school (years), work experience (months), previous unemployment experience (yes/no), number of own children, household size, age groups, survey wave dummies; ${ }^{a)}$ single-member households excluded. 
Table A21: Test of the buffering hypothesis based on fixed effects regressions: household income as additional control

\begin{tabular}{|c|c|c|c|c|c|c|}
\hline \multirow{2}{*}{$\begin{array}{l}\text { Dep. var.: mental health }(1-5) \\
\text { Indicator for social integration }\end{array}$} & \multicolumn{3}{|c|}{ Waves $1-10$} & \multicolumn{2}{|c|}{ Waves 3 and 5} & \multirow{2}{*}{$\begin{array}{c}\text { Waves } 3,5 \text { and } 9 \\
\begin{array}{c}\text { Job search social } \\
\text { support }\end{array}\end{array}$} \\
\hline & Weak ties & Strong ties & $\begin{array}{l}\text { Tensions and } \\
\text { conflicts }^{\mathrm{d})}\end{array}$ & $\begin{array}{l}\text { Employed } \\
\text { confidants }\end{array}$ & $\begin{array}{c}\text { General } \\
\text { social } \\
\text { support }\end{array}$ & \\
\hline & $\begin{array}{l}\text { Model } 1 \\
\text { Coef. }\end{array}$ & $\begin{array}{l}\text { Model } 2 \\
\text { Coef. }\end{array}$ & $\begin{array}{l}\text { Model } 3 \\
\text { Coef. }\end{array}$ & $\begin{array}{l}\text { Model } 4 \\
\text { Coef. }\end{array}$ & $\begin{array}{l}\text { Model } 5 \\
\text { Coef. }\end{array}$ & $\begin{array}{c}\text { Model } 6 \\
\text { Coef. }\end{array}$ \\
\hline Employment status (ref.: employed) ${ }^{a) b}$ & & & & & & \\
\hline Unemployed $\left(\beta_{3}\right)$ & $\begin{array}{c}-0.220 * * * \\
(0.018)\end{array}$ & $\begin{array}{c}-0.269 * * * \\
(0.030)\end{array}$ & $\begin{array}{c}-0.267 * * * \\
(0.039)\end{array}$ & $\begin{array}{l}-0.108 \\
(0.082)\end{array}$ & $\begin{array}{l}-0.354^{*} \\
(0.171)\end{array}$ & $\begin{array}{c}-0.227 * \\
(0.097)\end{array}$ \\
\hline Indicator for social integration $\left(\gamma_{2}\right)$ & $\begin{array}{c}0.004 \\
(0.009)\end{array}$ & $\begin{array}{c}0.032 * * * \\
(0.009)\end{array}$ & $\begin{array}{c}0.135 * * * \\
(0.008)\end{array}$ & $\begin{array}{l}0.059^{*} \\
(0.023)\end{array}$ & $\begin{array}{c}0.003 \\
(0.025)\end{array}$ & $\begin{array}{l}-0.012 \\
(0.018)\end{array}$ \\
\hline Indicator for social integration * unemployed $\left(\delta_{2}\right)$ & $\begin{array}{l}-0.003 \\
(0.017)\end{array}$ & $\begin{array}{c}0.027 \\
(0.014)\end{array}$ & $\begin{array}{c}0.024 \\
(0.013)\end{array}$ & $\begin{array}{c}-0.053 \\
(0.036)\end{array}$ & $\begin{array}{c}0.030 \\
(0.031)\end{array}$ & $\begin{array}{c}0.008 \\
(0.026)\end{array}$ \\
\hline Controls included? ${ }^{\mathrm{c}}$ & yes & yes & yes & yes & yes & yes \\
\hline Within $\mathrm{R}^{2}$ & 0.006 & 0.006 & 0.018 & 0.006 & 0.006 & 0.005 \\
\hline $\begin{array}{l}\text { Observations } \\
\text { (persons) }\end{array}$ & $\begin{array}{c}88,268 \\
(19,159) \\
\end{array}$ & $\begin{array}{c}88,268 \\
(19,159) \\
\end{array}$ & $\begin{array}{c}67,088 \\
(15,061) \\
\end{array}$ & $\begin{array}{c}9,822 \\
(4,942) \\
\end{array}$ & $\begin{array}{c}9,822 \\
(4,942) \\
\end{array}$ & $\begin{array}{l}14,094 \\
(5,652) \\
\end{array}$ \\
\hline
\end{tabular}


Table A22: Linear probability fixed effects regression of single vs. multi person household

\begin{tabular}{l|c}
\hline & Waves $1-10$ \\
\hline Dependent variable & Household size \\
\hline & Model 1 \\
Employment status (ref.: employed) & \\
Unemployed & 0.007 \\
& $(0.004)$ \\
Out of Labor force & -0.004 \\
& $(0.004)$ \\
Controls included?a) & yes \\
\hline Within $\mathrm{R}^{2}$ & 0.012 \\
\hline $\begin{array}{l}\text { Observations } \\
\text { (persons) }\end{array}$ & 89,184 \\
\hline$* * * p<0.001, * * p<0.01, * p<0.05 ;$; robust standard errors in parentheses. \\
$\begin{array}{l}\text { Data source: Panel "Labor Market and Social Security"; estimator: linear fixed effects; } \\
\text { own calculations; }{ }^{a} \text { controls: general-education and vocational school (years), work } \\
\text { experience (months), previous unemployment experience (yes/no), number of own children, } \\
\text { age groups, survey wave dummies. }\end{array}$ \\
\hline \hline
\end{tabular}

